\title{
In Vitro Bioactive Response of VERO-cells on Polymethyl-Methacrylate Craniofacial Implants altered with Hydroxy-Apatite/Carboxymethylcellulose
}

\author{
Colcha Danny, Mechanical Engineer ${ }^{1}$, Cáceres Jefferson, Mechanical Engineer ${ }^{2}$, Loayza Francis, $\mathrm{PhD}^{1}$, Falcones \\ Ondina, Biologist ${ }^{3}$, and Baykara Haci, $\mathrm{PhD}^{4}$ \\ 1Escuela Superior Politécnica del Litoral, Ecuador, dpcolcha@espol.edu.ec, floayza@espol.edu.ec \\ ${ }^{2}$ Escuela Superior Politécnica del Litoral, Ecuador, jefalcac@espol.edu.ec \\ ${ }^{3}$ Escuela Superior Politécnica del Litoral, Ecuador, ofalcone@espol.edu.ec \\ ${ }^{4}$ Escuela Superior Politécnica del Litoral, Ecuador, hbaykara@espol.edu.ec
}

\begin{abstract}
In Ecuador, intraoperative fabrication of polymethylmethacrylate (PMMA) craniofacial-implants is the norm when small sizes and simple geometry implants are required; this method has high infection risk, is inaccurate and unaesthetic. In this work we present a process for preoperative fabrication of craniofacial-implants using PMMA. For this study, a tomographic image of the head of a patient with a parietotemporal defect was used, the defect was then reconstructed using Blender ${ }^{\circledR}$ and Autodesk-Inventor ${ }^{\circledR}$ to generate a model of the implant. A 3D-printed model was used to fabricate a silicon-rubber mold; finally the implant was produced by casting. PMMA was also altered with $\mathrm{Hy}$ droxyapatite/Carboxymethyl-cellulose $(\mathrm{Hap} / \mathrm{CMC})$ in order to improve its bioactivity. VERO-cells were then used to test proliferation and adhesion on different combinations of PMMA/Hap/CMC. Results showed that probes altered with 5\%-Vol Hap and 10\%-Vol CMC had significantly better cell-growth when compared to unaltered-PMMA (Tukey HSD); in contrast, materials altered solely with carboxymethylcellulose showed cell-growth inhibitions/death. Overall, this manufacture approach showed highly aesthetic and functional outcomes when the final implant was compared against the 3D-printed skull defect, which renders this method as a viable option for the fabrication of PMMA implants meant to replace missing bone-flaps. Likewise, in vitro tests with Vero-cells suggest an improvement of implant-bioactivity with the addition of 5\%-Vol hydroxyapatite and 10\%-Vol CMC.

Keywords-Craniofacial, polymethylmethacrylate, 3D-printing, VERO, bioactivity.
\end{abstract}

Digital Object Identifier (DOI):

http://dx.doi.org/10.18687/LACCEI2016.1.1.080

ISBN: 978-0-9822896-9-3

ISSN: 2414-6390

14 ${ }^{\text {th }}$ LACCEI International Multi-Conference for Engineering, Education, and Technology: "Engineering Innovations for Global Sustainability", 20-22 July 2016, San José, Costa Rica. 


\title{
In vitro bioactive response of VERO-cells on polymethyl- methacrylate craniofacial implants altered with hydroxy- apatite/carboxymethylcellulose
}

\author{
Colcha Danny, Mechanical Engineer ${ }^{1}$, Cáceres Jefferson, Mechanical Engineer ${ }^{2}$, and Loayza Francis, $\mathrm{PhD}^{1}$ \\ ${ }^{1}$ Escuela Superior Politécnica del Litoral, Ecuador, dpcolcha@espol.edu.ec, floayza@espol.edu.ec \\ ${ }^{2}$ Escuela Superior Politécnica del Litoral, Ecuador, jefalcac@espol.edu.ec \\ ${ }^{3}$ Escuela Superior Politécnica del Litoral, Ecuador, ofalcone@espol.edu.ec \\ ${ }^{4}$ Escuela Superior Politécnica del Litoral, Ecuador, hbaykara@espol.edu.ec
}

\begin{abstract}
In Ecuador, intraoperative fabrication of polymethylmethacrylate (PMMA) craniofacial-implants is the norm when small sizes and simple geometry implants are required; this method has high infection risk, is inaccurate and unaesthetic. In this work we present a process for preoperative fabrication of craniofacial-implants using PMMA. For this study, a tomographic image of the head of a patient with a parietotemporal defect was used, the defect was then reconstructed using Blender ${ }^{\circledR}$ and Autodesk-Inventor ${ }^{\circledR}$ to generate a model of the implant. A 3D-printed model was used to fabricate a silicon-rubber mold; finally the implant was produced by casting. PMMA was also altered with $\mathrm{Hy}$ droxyapatite/Carboxymethyl-cellulose (Hap/CMC) in order to improve its bioactivity. VERO-cells were then used to test proliferation and adhesion on different combinations of PMMA/Hap/CMC. Results showed that probes altered with 5\%-Vol Hap and 10\%-Vol CMC had significantly better cell-growth when compared to unaltered-PMMA (Tukey HSD); in contrast, materials altered solely with carboxymethylcellulose showed cell-growth inhibitions/death. Overall, this manufacture approach showed highly aesthetic and functional outcomes when the final implant was compared against the 3D-printed skull defect, which renders this method as a viable option for the fabrication of PMMA implants meant to replace missing bone-flaps. Likewise, in vitro tests with Vero-cells suggest an improvement of implant-bioactivity with the addition of 5\%-Vol hydroxyapatite and 10\%-Vol CMC.
\end{abstract}

Keywords-Craniofacial, polymethylmethacrylate, 3Dprinting, VERO, bioactivity.

\section{INTRODUCTION}

A craniofacial defect is a modification in the anatomy and morphology of the bone in this region, which could be congenital or acquired as a result of neurosurgical procedure. In Ecuador, 8.726 cases of intracranial traumatisms were registered just in 2014 , corresponding to the $8^{\text {th }}$ cause of male morbidity with 6.232 incidents and 2.494 belonging to female. Out of these 8.726 cases, Pichincha and Guayas provinces had the greatest numbers of incidents in 2014, with 1.632 and 1.355 cases respectively [1]. Every year, $55 \%$ of these incidents require surgical treatment in the craniofacial region [2].

Nowadays, procedures that repair these defects are complicated due to the complex anatomy involved and the requirement of highly aesthetic results. The main objectives of craniofacial reconstruction are: Restoring the protective barriers for intracranial structures in the skull, present pleasing aes-

Digital Object Identifier (DOI):

http://dx.doi.org/10.18687/LACCEI2016.1.1.080

ISBN: 978-0-9822896-9-3

ISSN: 2414-6390

14 ${ }^{\text {th }}$ LACCEI International Multi-Conference for Engineering, Education, and Technology: "Engineering Innovations for Global Sustainability", 20-22 July 2016, San José, Costa Rica. thetic results, retrieve a permanent and durable reconstruction and in some cases bring back functionality of the damaged area [3]. The consequences of poor-quality interventions often results in unaesthetic outcomes which may disturb the psychological state and social interaction of the patient [4].

A great variety of methods have been studied in order to repair craniofacial defects; autologous and/or allogenic bone grafts; and alloplastic bone substitutes are among the most common [5]. Although autologous grafts are always the first option, their extraction often comes with complications associated with the geometry of the extraction area which limits the shape and the final aesthetic result; and medical difficulties that may be presented at the donor site such as storage and age discrepancy of the donor, which are also a downside in allogenic bone grafts $[6,7]$.

On the other hand, numerous alloplastic materials have also been proven to be highly biocompatible such as: Polymethylmethacrylate (PMMA), Polyetheretherketone (PEEK), titanium alloys, stainless steel, chrome-cobalt alloys and ceramics such as Hydroxyapatite (HAp), to name a few [8]. While most of these materials are biocompatible, they are not naturally bioactive (except for titanium and HAp); this limits the implant materials surgeons can use in cases where the ability of implant-bone merging is necessary [9].

However, recent breakthroughs in biomedical technology have been reported in the development of osteoconductive alloplastic materials $[6,7,10,11]$. These osteoconductive counterparts differ in their ability to merge with the surrounding bone and improve anchorage of the implant at the boneimplant interface [12]. This osteoconductivity is mainly achieved by adding bioactive materials such as: Bioglass $₫$, bioglass-ceramics, calcium phosphate ceramics or hydroxyapatite [13]; or by increasing the porosity of the PMMA matrix with the aid of CMC or alginate microparticles $[14,15]$, thus improving implant bioactivity by allowing bone ingrowth to the implant.

Regarding simple geometry/implantation craniofacial defects, PMMA implants are the most widely used due to their low-price, high malleability, radiopaque characteristics, resistance, light weight and of course biocompatibility [9]. In Ecuador; when the implantation and geometry of the defect is simple, the usual approach is to replace the damaged bone flap 
with intraoperative PMMA implants [16, 17]. Intraoperative PMMA implants can be harmful to the patient due to thermal and chemical necrosis of the surrounding tissue when exothermic heat of polymerization occurs, as well as infection, decrease in blood pressure or allergic reactions caused by leaking of unpolymerized monomer [11, 18].

The aim of this study is to develop an alternative protocol for the design and manufacture of PMMA preoperative craniofacial-implants with the aid of 3D printing and silicon-rubber mold technics (SRM) [19]. This protocol is considered alternative due to the fact that it uses free software for segmentation of the skull and reconstruction of the implant thus offering an indisputable monetary advantage compared to its paidsoftware counterparts. On the other hand, the purpose of preoperative fabrication of PMMA implants is to avoid the disadvantages present in the intraoperative procedure; due that the exothermic heat produced by the polymerization is happening outside the body and being given enough time to finish. Additionally, the PMMA matrix was altered with Hap or CMC in order to study their bioactive and porogenic properties in the matrix [20]. Finally, bioactive tests were conducted in order to compare proliferation/adhesion of VERO cells in different compositions and partially demonstrate the bioactive improvement of PMMA [21, 22].

\section{MATERIALS AND METHODS}

\section{Acquisition of tomographic images}

Axial tomographic images of the subject's head were provided in 'Digital Imaging and Communication in Medicine' (DICOM) format, these belonged to a 33 year old male patient. The patient suffered from an intracranial traumatism and was submitted for a decompressive craniectomy short afterwards. The resulting parietotemporal defect in his left side was measured in the axial, coronal and sagittal axes with $82.59 \mathrm{~mm}$, $80.45 \mathrm{~mm}$ and $83.77 \mathrm{~mm}$ respectively. The axial cuts were 1 $\mathrm{mm}$ of thickness and give a total of 301 slices recollected by the axial computerized tomograph (TOSHIBA aquilion).

\section{Image segmentation}

DICOM images were imported to 3DSLICER (Magn Reson Imagin. 2012 Nov). The segmentation was then conducted using the threshold technique with values between 230 and 270 in the Hounsfield scale. Finally the segmented image of the skull was exported in Stereo Lithography (STL) format.

\section{Reconstruction of the craniofacial defect}

The tridimensional-image in STL. format was reconstructed using BLENDER (Amsterdam: Blender Foundation, 1998). The basic idea was to mirror the entire skull by a midsagittal plane and then perform the Boolean operation of subtracting this mirrored-skull from the original in order to obtain a 3D-model of the missing bone flap. However, due to the position of the CT-scanning a mid-sagittal plane of symmetry was approximated by using well-defined features of the skull (nose and eye cavities). The 3D-model of the implant was manually fixed utilizing Blender software's tools and then exported in STL. to be 3D-printed (PROJECT 3510 SD, 3DS). The defect of the skull was also 3D-printed in ceramic (ZPRINTER 310 Plus, ZCorporation) in order to later test the accuracy, proper fit of the implant and the final aesthetic result.

\section{Manufacture of the probes}

Zimmer Bone-Cement (Dough Type) was used to fabricate probes $15 \mathrm{~mm}$ in diameter and $2 \mathrm{~mm}$ in thickness. Zimmer Bone-Cement package contains: 40 grams of Polymethylmethacrylate containing barium sulfate and $20 \mathrm{ml}$ of a liquid component containing mainly methylmethacrylate $(97.25 \%)$. The manufacturer suggests the use of a 1:1 ratio (polymer powder/liquid monomer) for Dough type bone cement, but since a low viscosity bone cement was needed in order to be able to inject it into a mold cavity; a 0.75:1 ratio was used. Also, in order to stretch handling time, prechilling of the liquid monomer in $-4{ }^{\circ} \mathrm{C}$ was necessary. Additionally, a geometric model of a cubic cell containing spheres was used to approximately correct the volume represented by the powder in order to fill the empty spaces (air) between the PMMA/Hap spheres and wet all the components completely.

Carboxymethylcellulose was used to manufacture porous probes; this material was mixed with water $(40 \mathrm{mg} / \mathrm{mL})$ in order to form a gel. The gel was then mixed with the powder components of the bone cement and then the process continued according to the manufacturer's manual. On the other hand probes containing Hydroxyapatite were manufacture by first mixing all the powder components (PMMA and Hap) in the respective volume percentages and then adding the liquid monomer. In both cases, the volume percentage of liquid monomer was calculated in a manner so that it will only react with the powder components in the mixture, i.e. Hap and PMMA. In order to sterilize probes, they were washed 3 times with hot water (approximately $88{ }^{\circ} \mathrm{C}$ ), then rinsed one last time with cold water, disinfected with $99 \%$ ethanol and placed in UV camera for 15 minutes.

Table I and Table II show 5 different compositions studied, where every probe was replicated 12 times accounting for 3 days of experimentation.

\section{Improvement of surface bioactivity}

In order to prove bioactivity enhancement of the PMMA, VERO-cells (African green monkey kidney cells) were cultivated for 24 hours in a $\mathrm{CO}_{2}$ Incubator at $37{ }^{\circ} \mathrm{C}$ and $5 \% \mathrm{CO}_{2}$ with Dulbecco's Modified Eagle Medium (DMEM, Gibco), supplemented with $10 \%$ fetal bovine serum and $1 \mathrm{X}$ Antibiotic-Antimycotic at an initial population of $6 \times 10^{4}$ cells.

After incubation, cells were distributed among 3 different 24well cell-culture plates containing the different probes and a control so that they could be studied in intervals of 24,48 and 72 hours. Cells cultivated directly on polystyrene at $37{ }^{\circ} \mathrm{C}$ and $5 \% \mathrm{CO}_{2}$ in a solution with DMEM, $10 \%$ fetal bovine serum, $1 \mathrm{X}$ Antibiotic-Antimycotic were used as a control, representing the best case-scenario for cell-growth and simultaneously

14 ${ }^{\text {th }}$ LACCEI International Multi-Conference for Engineering, Education, and Technology: "Engineering Innovations for Global Sustainability", 20-22 July 2016, San José, Costa Rica. 
acting as the maximum cell-growth limit. Every day, cells from each composition were cleaved with Trypsin-EDTA $0.25 \%$ and then dyed with Trypan Blue stain $0.4 \%$ in order to perform 4 random cell counts (per composition, including the control) with a hemocytometer. An N-WAY ANOVA $(\mathrm{p}<$ $0.05)$ was performed to determine cell-growth differences be- tween substrates. Later on, a ONE-WAY ANOVA ( $\mathrm{p}<0.05)$ analyzed daily differences among substrates and Tukey HSD was used to compare them against probe D (unaltered bone cement) and each other in order to determine if the differences were significant.

Table I

Composition of substrates A-C with Carboxymethylcellulose and hydroxyapatite as porogenic and bioactive agents

\begin{tabular}{|c|c|c|c|c|c|c|c|c|c|}
\hline \multirow[t]{2}{*}{ Material } & \multicolumn{3}{|c|}{ Substrate A } & \multicolumn{3}{|c|}{ Substrate B } & \multicolumn{3}{|c|}{ Substrate C } \\
\hline & $\%$ Volume. & grams & $\mathrm{mL}$ & $\%$ Volume. & grams & $\mathrm{mL}$ & $\%$ Volume. & grams & $\mathrm{mL}$ \\
\hline $\begin{array}{c}\text { Porosity [CMC + } \\
\left.\mathrm{H}_{2} \mathrm{O}\right]\end{array}$ & $40,0 \%$ & & & $20,0 \%$ & & & $10,0 \%$ & & \\
\hline PMMA & $60,0 \%$ & 1,560 & $\begin{array}{c}2,40 \\
0\end{array}$ & $80,0 \%$ & 2,080 & $\begin{array}{c}3,20 \\
0 \\
\end{array}$ & $85,0 \%$ & 2,210 & $\begin{array}{c}3,40 \\
0 \\
\end{array}$ \\
\hline MMA $(1: 0,75)$ & - & 0,978 & $\begin{array}{c}1,04 \\
0\end{array}$ & - & 1,304 & $\begin{array}{c}1,38 \\
7 \\
\end{array}$ & - & 1,385 & $\begin{array}{c}1,47 \\
3\end{array}$ \\
\hline $\mathrm{CMC}$ & $1,6 \%$ & 0,101 & $\begin{array}{c}0,06 \\
4 \\
\end{array}$ & $0,8 \%$ & 0,051 & $\begin{array}{c}0,03 \\
2 \\
\end{array}$ & $0,4 \%$ & 0,025 & $\begin{array}{c}0,01 \\
6 \\
\end{array}$ \\
\hline Water & $38,4 \%$ & 1,536 & $\begin{array}{c}1,53 \\
6\end{array}$ & $19,2 \%$ & 0,768 & $\begin{array}{c}0,76 \\
8\end{array}$ & $9,6 \%$ & 0,384 & $\begin{array}{c}0,38 \\
4\end{array}$ \\
\hline Hap & - & & & - & & & $5,0 \%$ & 0,268 & $\begin{array}{c}0,20 \\
0\end{array}$ \\
\hline Total volume & & & $\begin{array}{c}4,00 \\
0\end{array}$ & & & $\begin{array}{c}4,00 \\
0\end{array}$ & & & $\begin{array}{c}4,00 \\
0\end{array}$ \\
\hline
\end{tabular}

Table II

Nonporous composition of Substrate D and Substrate E (hydroxyapatite as bioactive agent)

\begin{tabular}{ccccccc}
\hline \multirow{2}{*}{ Material } & \multicolumn{3}{c}{ Substrate D } & \multicolumn{3}{c}{ Substrate E } \\
\cline { 2 - 8 } & Volume. & Grams & $\mathrm{mL}$ & Volume. & Grams & $\mathrm{mL}$ \\
\hline PMMA & $100 \%$ & 2,600 & 4,000 & $70 \%$ & 1,820 & 2,800 \\
\hline MMA (1:0,75) & - & 2,569 & 2,733 & - & 2,081 & 2,213 \\
\hline Hap & - & - & - & $30 \%$ & 1,608 & 1,200 \\
\hline Total Volume & - & & 4,000 & - & & 4,000 \\
\hline
\end{tabular}

\section{Optical Microscopy}

Images of each well (A,B,C,D,E,Control) were taken in the MOTIC AE30-21 inverted microscope every 24 hours with the MOTICAM PRO 282B in order to observe changes in cell-growth and register cell development at $10 \mathrm{X}$ magnification. Finally, 2 wells per composition (except control) were fixed with paraformaldehyde $4 \%$ diluted in phosphate buffered saline (PBS) and incubated at room temperature for an hour; eventually the medium (containing paraformaldehyde) was removed and fresh PBS was added in order to take images of the probe's surface with the aid of the ZEISS upright microscope (20X magnification) and an external CANON Powershot 14.7 pixels camera. Cell growth on top of the different materials was expected and qualitative characterization of the material's bioactivity was performed.

\section{Manufacture of the implant}

A silicon rubber mold was fabricated using the $3 \mathrm{D}$ printed model of the implant. Sprues for injection and escape of the material were added on opposite limits of the implant's mold. The mold was left to dry for 3 hours until it set, then cut open to remove the implant model and resealed in order to be used. Polymethylmethacrylate-based Zimmer Bone Cement in 0.75:1 ratio was injected into the mold until the material came out from the escape sprue. Finally the implant's accuracy was qualitatively tested against the 3D-printed defect of the skull.

\section{RESULTS}

\section{Improvement of surface bioactivity}

Cells cultivated in the control group proved to have the largest cell count in each day, leading the group as a maximum cell growth limit as expected. The analysis of N-WAY ANOVA showed that there were no major differences between daily replicas per composition $(F=0.49, p>0.05)$. Results of the $\mathrm{N}$-Way Anova also exhibited dependence of replications on

$14^{\text {th }}$ LACCEI International Multi-Conference for Engineering, Education, and Technology: "Engineering Innovations for 
sample compositions $(\mathrm{F}=2.13, \mathrm{p}<0.05)$, and dependence of daily samples on replications $(\mathrm{F}=2.4, \mathrm{p}<0.05)$, both which are logical and will not be analyzed. The interaction to be analyzed is SUBSTRATE*DAY as shown on Fig.1, which represents the dependence of daily cell count on the different substrates $(\mathrm{F}=59.41, \mathrm{p}<0.05)$.

Day 1. - In the first 24 hours cells in substrate A, B and C developed in a way that did not show significant differences against probe D (Tukey HSD). In the first day, only substrate E showed to have improved cell growth compared to D. In all cases cell counts were below the upper limit constrained by the Control substrate (Tukey HSD).

Day 2. - After 48 hours, only probe A had no significant difference against probe D (Tukey HSD). The rest of the probes showed significant differences, regarding positive and negative behaviors. Positive results represent enhancement on proliferation of cells in substrates $\mathrm{C}$ and $\mathrm{E}$, with $\mathrm{C}$ having substantially higher cell count than E, but still below the upper limit imposed by the Control substrate (Tukey HSD). Negative results in substrate $B$, showed a significant decrease in cell count compared to D (Tukey HSD).

Day 3. - After 72 hours of experimentation the same results were observed. Substrate B showed bioactive decrease compared to $\mathrm{D}$ and substrate A proved being not significantly different than D (Tukey HSD). Again substrate $\mathrm{C}$ and $\mathrm{E}$ showed improvements on cell proliferation; with $\mathrm{C}$ being better than D, not significantly different than $\mathrm{E}$ but still below the Control substrate (Tukey HSD).

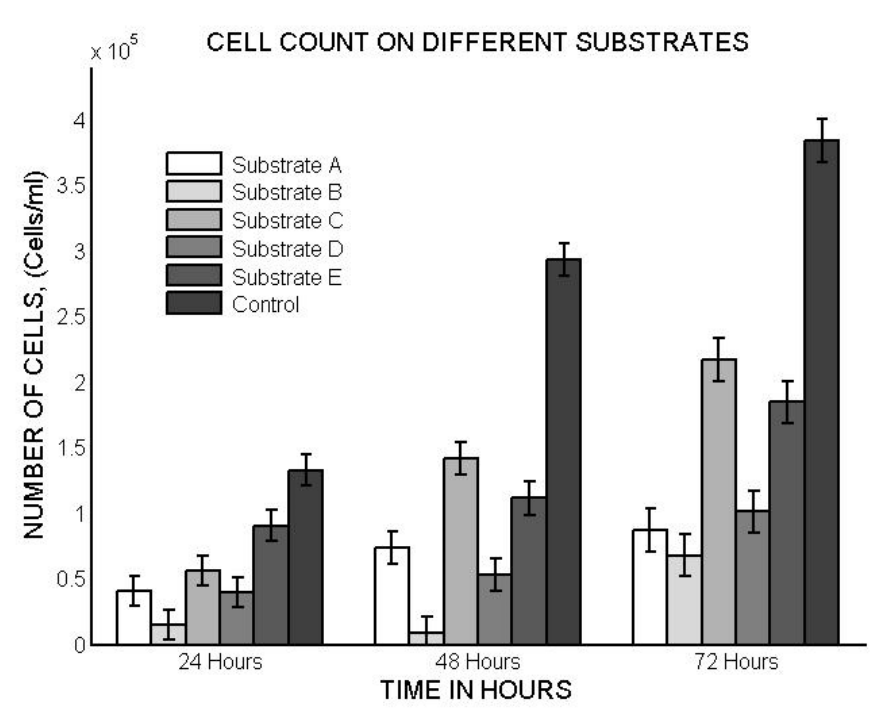

Fig. 1. Daily cell-growth variations of VERO cells on different substrates
$(\mathrm{p}<0.05)$. Multi-comparison analysis performed by Tukey HSD

Fig. 1. Daily cell-growth variations of VERO cells on different subst
$(\mathrm{p}<0.05)$. Multi-comparison analysis performed by Tukey HSD
Optical Microscopy, qualitative assessment

-Cell culture, Day 1

Fig 2. shows the development of cell culture on the medium around the different probes. Substrate A and B showed signs of a dirty mediums with good development of VERO cells. On the other hand substrate $\mathrm{C}$ and $\mathrm{E}$ showed very good clear mediums as in substrate D and the Control. Cells on C, D and E look well grown, elongated and with very few signs of dead cells.

Fig. 3. shows the surface of the different substrates to partially demonstrate the bioactivity of the material. In Probe A and B, there's no sign of cell attachment on the surface. In contrast, substrate C, D and E show clear growth of healthy cells on their surfaces; with Probe D and E being the ones with visually higher proliferation of cells. Substrate E showed a much clear difference between cells boundaries, as they are more spaced and clearly defined compared to substrate D.

\section{-Cell culture, Day 2}

Fig. 4. Shows no major differences between Probe A and B from previous days as their medium looks dirty and cloudy; still cells appear to have developed correctly and are well grown and elongated. On the other hand, cells on probe $\mathrm{C}$ and E look very much as the Control, which shows they are healthy; unlike cells on probe $\mathrm{D}$, which look deteriorated as they are more spaced and less confluent as they were on day 1. 


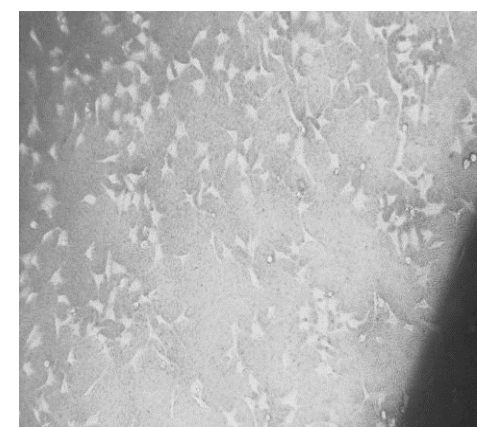

A

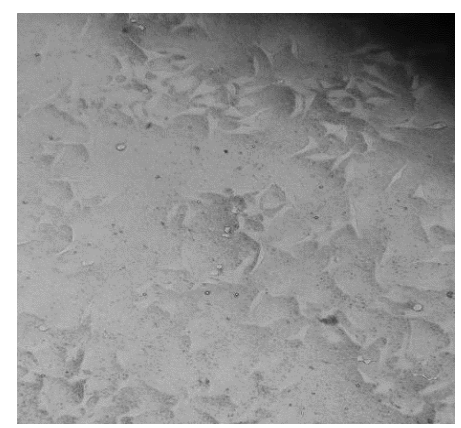

B

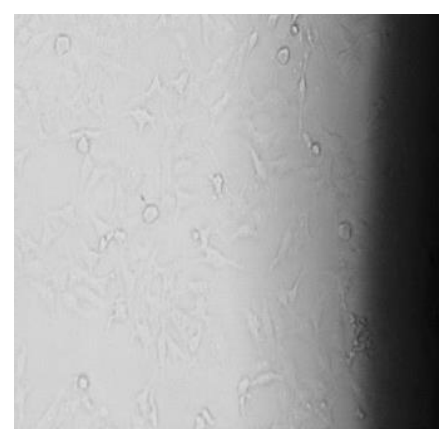

$\mathrm{C}$

Fig. 2. Cell growth on medium around different substrates (After 24 hours)

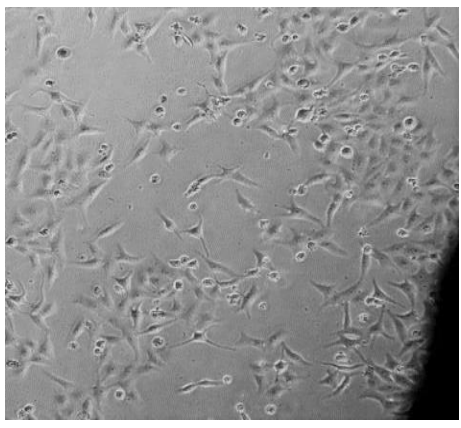

D

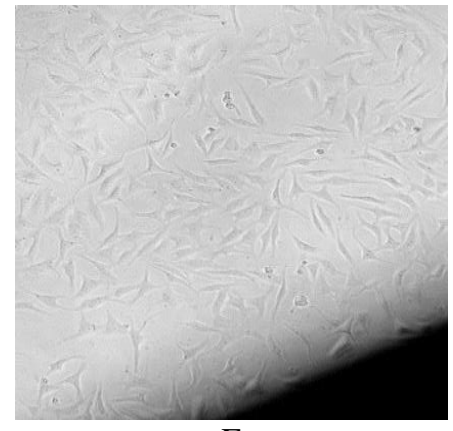

E

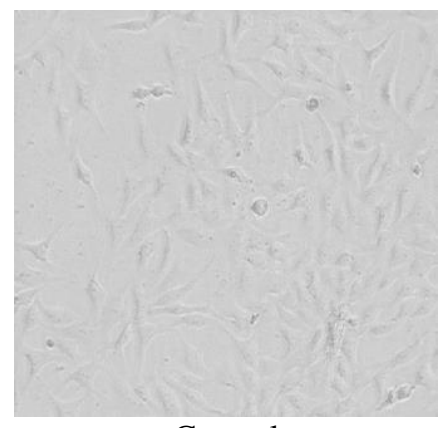

Control

Fig. 2. Cell growth on medium around different substrates (After 24 hours)

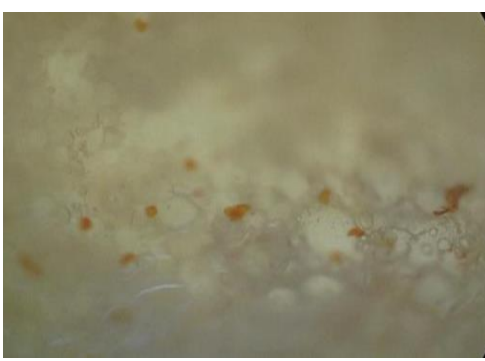

$\mathrm{A}_{1}$

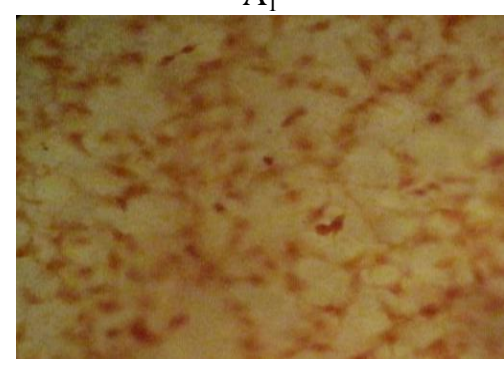

$\mathrm{D}_{1}$

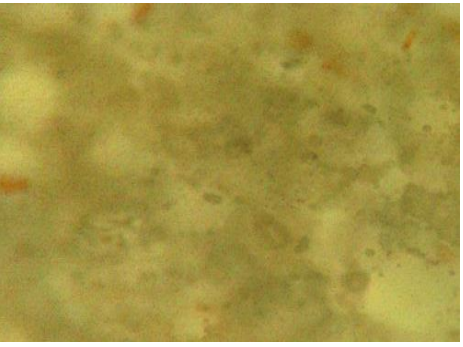

$\mathrm{B}_{1}$

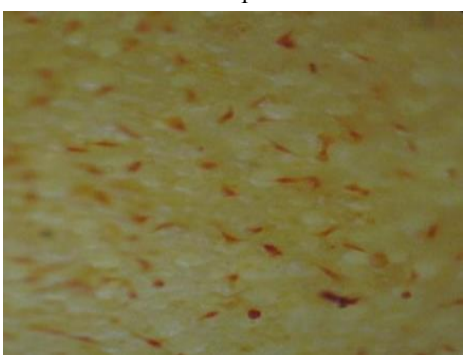

$\mathrm{E}_{1}$

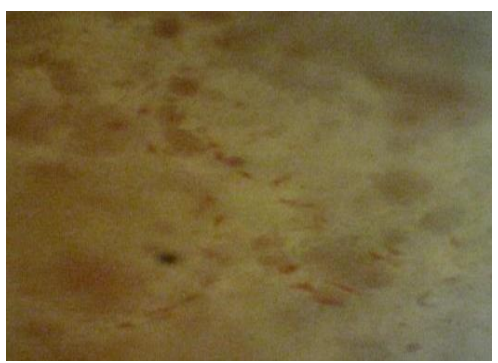

$\mathrm{C}_{1}$

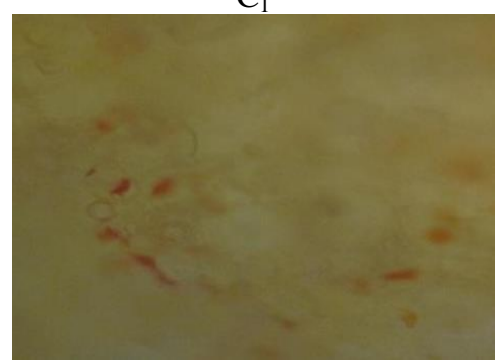

$\mathrm{A}_{2}$ 


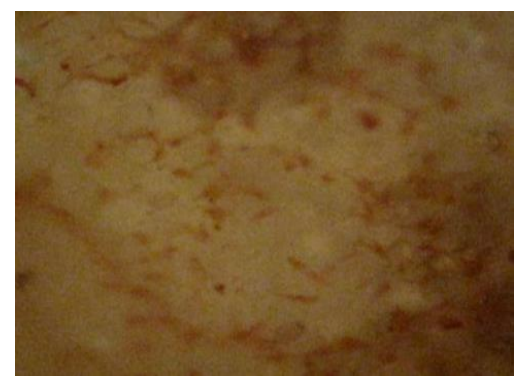

$\mathrm{B}_{2}$

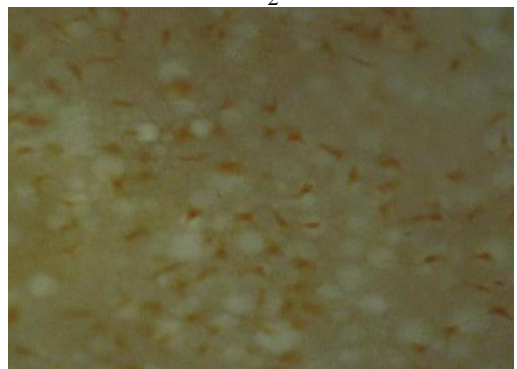

$\mathrm{E}_{2}$

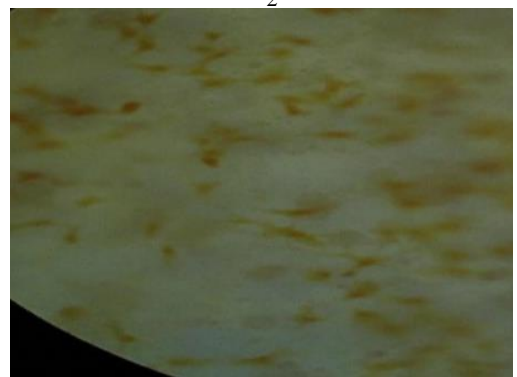

$\mathrm{C}_{3}$

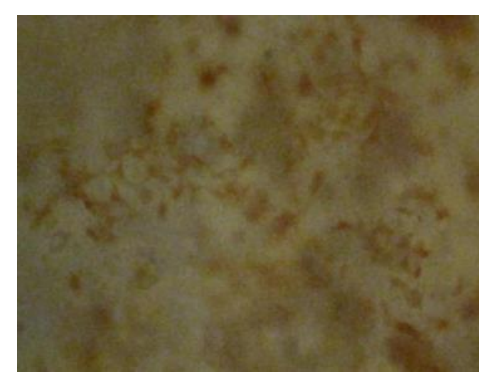

$\mathrm{C}_{2}$

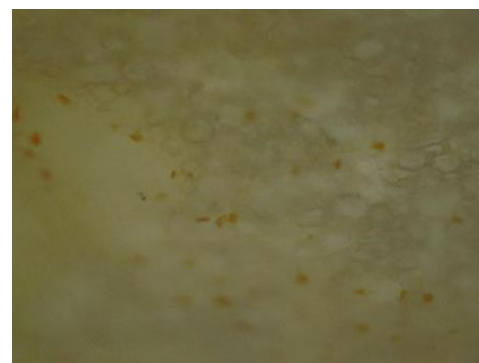

$\mathrm{A}_{3}$

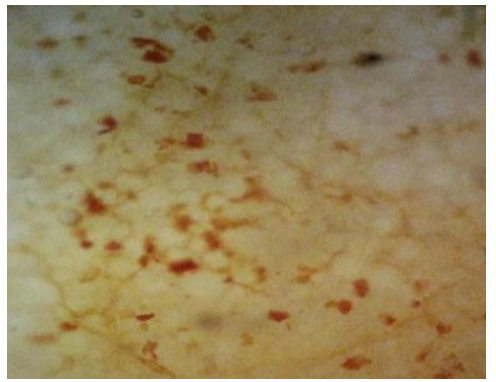

$\mathrm{D}_{3}$

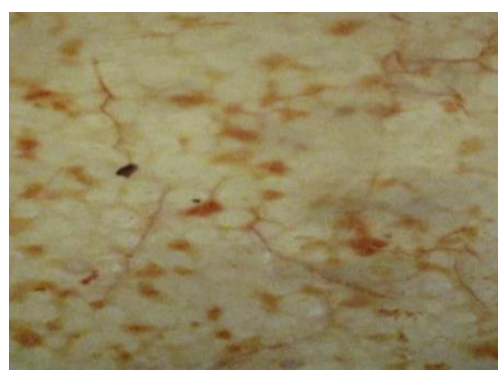

$\mathrm{D}_{2}$

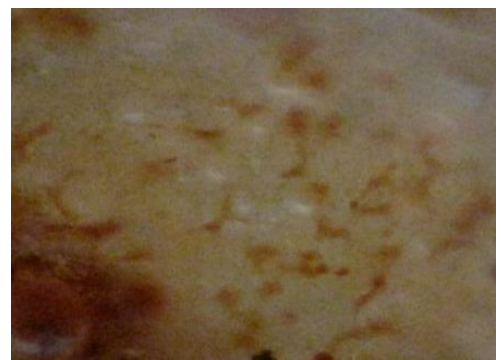

$\mathrm{B}_{3}$

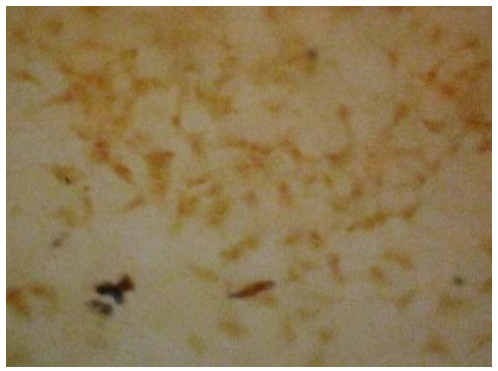

$\mathrm{E}_{3}$

Fig. 3. Cell proliferation and adhesion on the surface of different substrates. Subscripts stand for the day when the images were taken $\left(24 \mathrm{hours}_{1} ; 48 \mathrm{hours}_{2}\right.$; 72hours 3 )

A look at the material's surface Fig. 3, shows us the same results from previous days. Probe A has organic material that is dead, no sign of alive cells anywhere on its surface. In contrast, Probe B seemed to have developed a bioactive surface, since there are healthy cells attached to its surface. Probe C and $\mathrm{E}$ have a greater confluency of healthy cells compared to day 1 . On the contrary, cells on probe $\mathrm{D}$ seem to have lost its shape, they also look deteriorated as they no longer are elongated and well grown.

\section{-Cell culture, Day 3}

Last day of testing Fig. 5, cells from surrounding substrate A and $\mathrm{B}$ reached confluency but the medium is dirty and cloudy due to small unidentifiable particles. Again cells on Probe C, $\mathrm{D}$ and $\mathrm{E}$ look very healthy and the medium in all of them is clear, but full-confluency has only been reached on probe $\mathrm{C}$, as probe $\mathrm{D}$ and $\mathrm{E}$ are spaced and not filling the spaces completely.
Again, when the probe's surfaces were observed Fig. 3; substrate A showed no attachment of cell on its surface, just organic dead material. Also, the surface of substrate B showed no attachment of cells to the surface; except for a small portion shown in Fig. which depicts a small group of bigger cells compared to the other samples, suggesting deterioration or death of the cells. An interesting observation is that probe D showed organic stained material and a loss of shape of the attached cells, no cells attached to its surface were found. Instead, probe $\mathrm{C}$ and $\mathrm{E}$ showed to have an even greater confluency of attached cells than previous days. Cells on probe $\mathrm{E}$ look healthier, are more defined and conserve the shape of healthy VERO cells when compared to probe C; as cells attached to probe's $\mathrm{C}$ surface are more clumped and not well defined. 


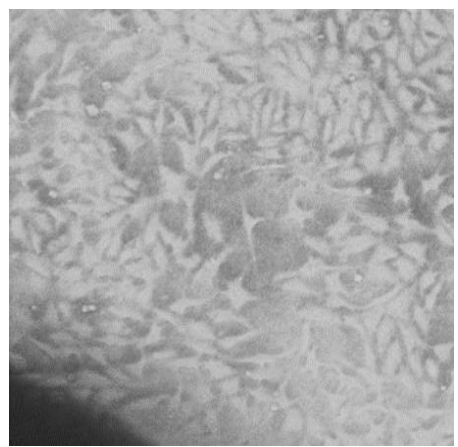

A

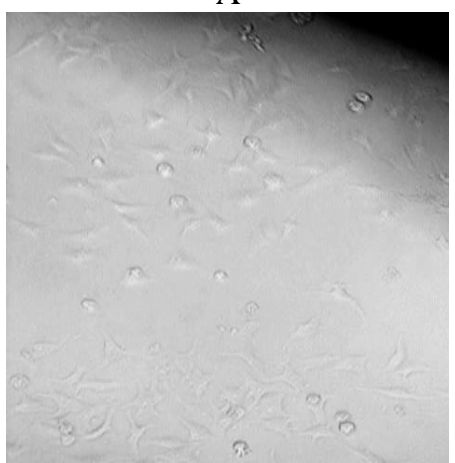

D

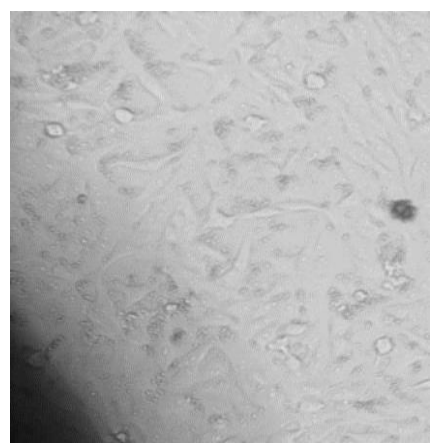

B

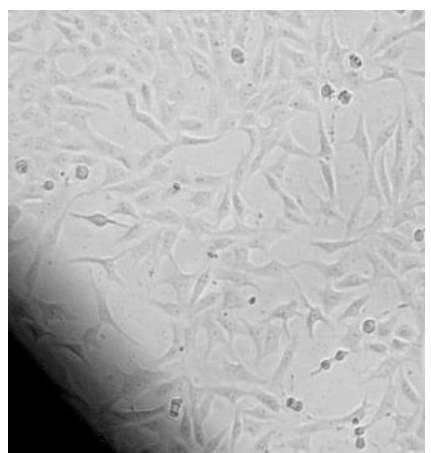

E

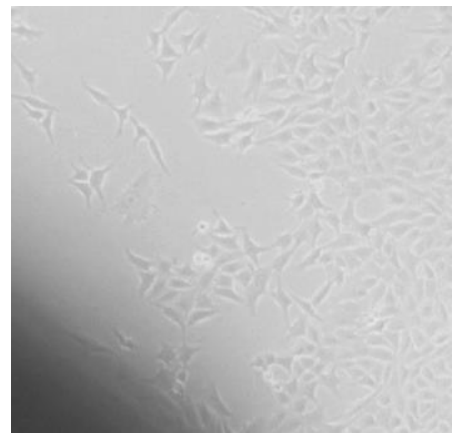

$\mathrm{C}$

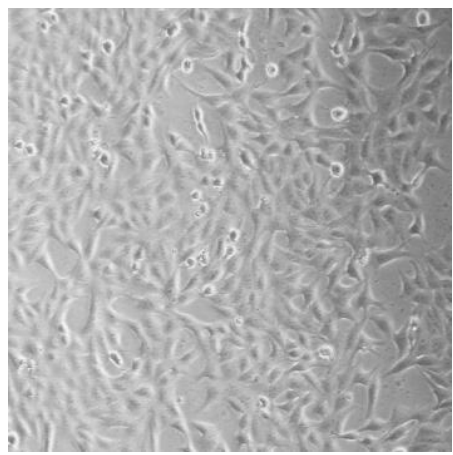

Control

Fig. 4. Cell growth on medium around different substrates (After 48 hours)

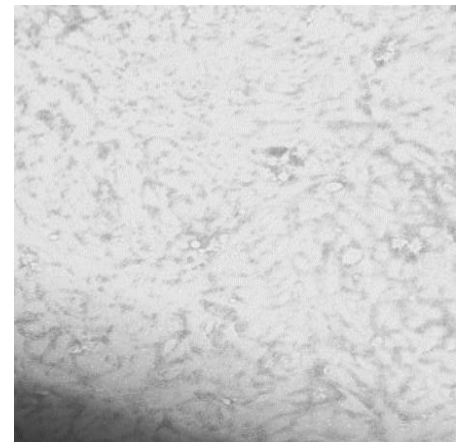

A

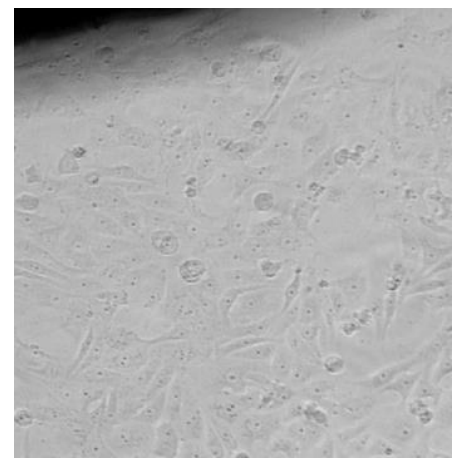

D

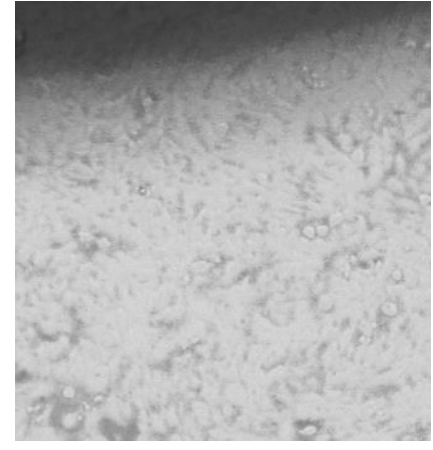

B

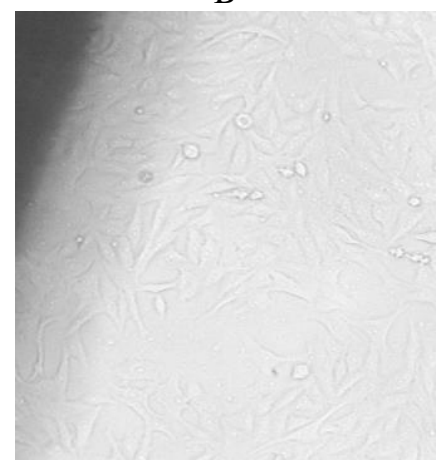

E

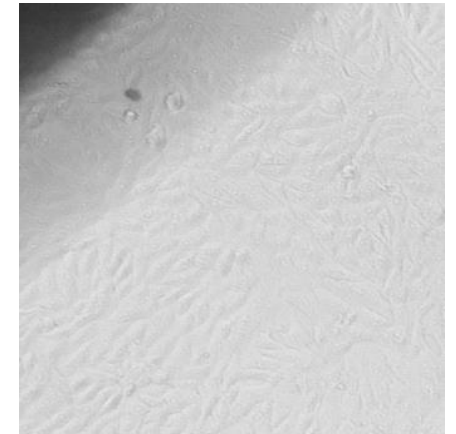

$\mathrm{C}$

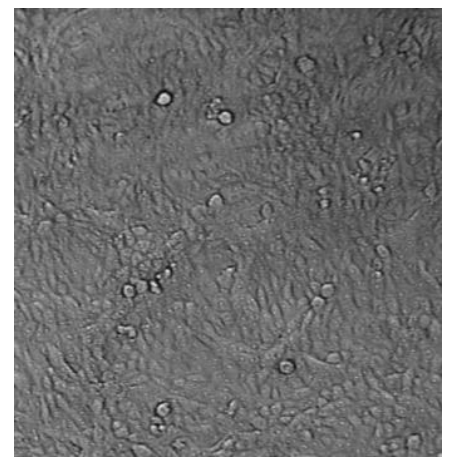

Control

Fig. 5. Cell growth on medium around different substrates (After 72 hours) 


\section{Manufacture of the implant}

In order to prove this process viability, SRM in conjunction with 3D-printing techniques were used to manufacture a simple bone cement implant (substrate D). Qualitative assessment of the implant's fitting and accuracy indicated very good adaptation of the implant to the defect and the contour of the skull, thus producing a highly pleasing aesthetic and functional result Fig. 6.

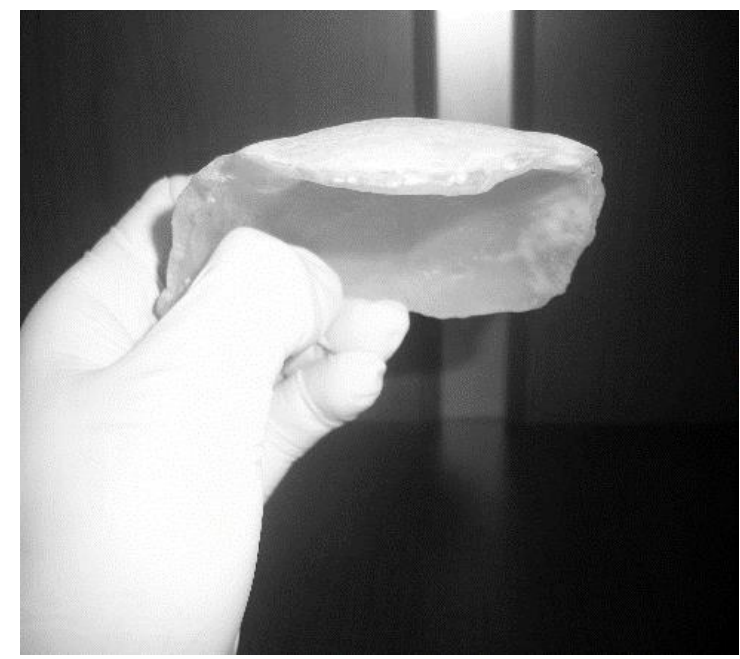

Fig. 6. a) Bone cement implant.

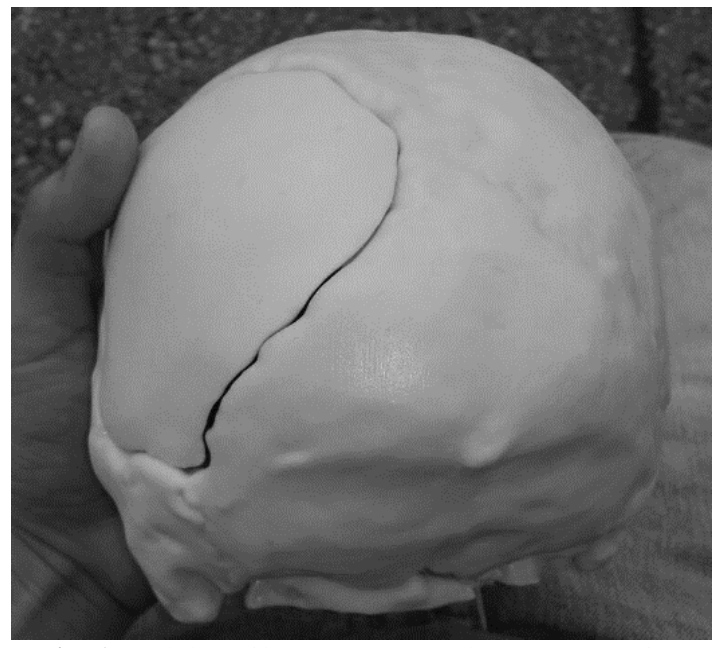

Fig. 6. b) Fitting of implant on the parietotemporal defect

\section{DISCUSSION}

\section{Improvement of surface bioactivity}

Results suggest that by the first day, surface bioactivity was significantly enhanced by the adding of hydroxyapatite alone, as showed by the results provided in substrate $E$ which exhibited a higher cell count, improvement on cell adhesion and proliferation on the substrate when compared to substrate D. Probes containing hydroxyapatite exhibited an overall bioac- tive behavior, thus increasing proliferation and adhesion of VERO cells to the substrate [23], even on probes containing as little as 5\% Hap (Substrate C). On the contrary, the decrease of living cells in probe A and B may be due to porous PMMA formulations often releasing unconverted methylmethacrylate (MMA) monomer [24]; this monomer is toxic for cells [25], which translates to death, enlargement and alteration of the shape of the cells as it was visually observed in microscopy. Fragmentation of the cells in probes A and B was also observed; these fragments were observed drifting in the medium and gave it the dirty and cloudy look we observed in the microscopy. As a result we consider that $\mathrm{CMC}$ gel as a porous agent in the percentages presented in probes $\mathrm{A}$ and $\mathrm{B}$, cannot be considered as enhancers of bioactivity due to the lack of adhesion of cells to the respective substrates; since in the case of probe $\mathrm{B}$, the porosity causes death and lack of adhesion of cells in the substrate; and in the case of probe A, no major differences in cell count were spotted and there was almost no adhesion or proliferation of VERO cells in the substrate, thus not presenting real improvement on bioactivity.

Together with probe $\mathrm{A}$ and $\mathrm{B}$, probe $\mathrm{C}$ also had a slow proliferation of cells due to it contained $10 \%$ porosity which would have also released toxic monomer. The fact that it recovered by the second and third day and reached probe E's cell count ( $0 \%$ porosity), may suggest the amount of porosity did not affect the overall development of cell growth (as it did with substrates A and B), as the content of unconverted MMA may have been negligible. On probe $\mathrm{D}$ we observed proliferation and a decreasing cell attachment on the substrate which could be attributed to the inherent surface roughness of the unaltered bone cement (since no bioactive components were introduced in the matrix); as surface roughness in biomaterials has been proven to induce adhesion and proliferation of cells in the substrate [26, 27]. Even though surface roughness may have played an important role on cell adhesion, in this case in particular it may have not been sufficient to maintain adhesion and support further proliferation, as deterioration of the shape of the cells was observed in optical microscopy. To further assess the degree in which cement surface roughness influenced bioactivity in the substrate, a surface roughness test must be conducted [28].

\section{Manufacture of the implant}

Regarding the quality and accuracy of fit of the implant, we can conclude that 3D-printing in conjunction with siliconrubber mold (SRM) techniques can produce high quality bone cement implants [29]; as the final result was tested visually on the cranial defect to demonstrate its accuracy and pleasing aesthetic result. All of this was possible due to the correct choosing of segmentation values for skull bones and the appropriate posterior reconstruction in Blender $®$; which suggest that free software like 3D-Slicer and Blender could be used as a cheaper alternative for craniofacial reconstruction of simple geometry defects (mainly calvarial bone defects) as it offers the same level of accuracy of other paid-software packages. 
The present study demonstrated that generic bone cement compositions can be altered in order to produce compositions with positive effects on VERO cell cultures; also 3D-printing along with SRM techniques were presented as an obvious cheap alternative in the manufacture of bioactive PMMA implants if paired up with free-software as 3D-Slicer ${ }^{\circledR}$ and Blender ${ }^{\circledR}$. In the future if implantation were to happen, studies including bone marrow derived mesenchymal stem cells need to be performed in a similar way VERO cells were applied to this study; with the addition of in vivo studies and a deeper examination on morphology of the porosity, assessment of cell adhesion at higher magnifications (SEM Imaging), surface roughness and chemical composition of the altered material.

\section{AKNOWLEDGEMENTS}

This work has been partially financed by 'Aplicación de prototipado rápido para la construcción de modelos e implantes ortopédicos' Investigation Project and is part of the Thesis 'Aplicación de técnicas de manufactura aditiva para la fabricación de implantes cráneo-maxilofaciales de polimetilmetacrilato'. The authors wish to express their gratitude to the 'Laboratorio de Biomedicina' ESPOL's team for their interest in this dissertation.

\section{REFERENCES}

1. Anuario camas Egresos Hospitalarios 2014. Dirección de estadísticas sociodemográficas: Instituto Nacional de Estadísticas y Censos, http://www.ecuadorencifras.gob.ec

2. Oñate C., Oñate D., Granda A., Arias C: Análisis Epidemiológico de Trauma Maxilofacial. Revista médica de nuestros hospitales. 18:14-19 (2012)

3. Artico M, Ferrante L, Pastore FS, Ramundo EO, Cantarelli D, Scopelliti $\mathrm{D}$, et al: Bone autografting of the calvaria and craniofacial skeleton. Surgical Neurology. 60(1):71-79 (2003)

4. Márquez M. F. L. Aspectos Psicológicos de pacientes que presentan hendidura Labio Palatina. Acta Odontológica Venezolana. 51( $\left.\mathrm{N}^{\circ} 2\right)$, (2013)

5. Bone Graft. Healthline: http://www.healthline.com/health/bone-graft

6. Cabraja M, Klein M, Lehmann T-N: Long-term results following titanium cranioplasty of large skull defects. Neurosurgical focus. 26(6):E10 (2009)

7. Breitbart AS, Ablaza VJ: Implant materials. Grabb and Smith's Plastic Surgery, 5th Ed Philadelphia: Lippincott-Raven. (1997)

8. Aydin S, Kucukyuruk B, Abuzayed B, Aydin S, Sanus GZ. Cranioplasty: Review of materials and techniques. J Neurosci Rural Pract. 2(2):162-167 (2011)

9. Navarro M, Michiardi A, Castano O, Planell J: Biomaterials in orthopaedics. Journal of The Royal Society Interface. 5(27):1137-1158 (2008).

10. Neumann A, Kevenhoerster K: Biomaterials for craniofacial reconstruction. GMS current topics in otorhinolaryngology, head and neck surgery. Vol 9 (2009)

11. Chu KT, Oshida Y, Hancock EB, Kowolik MJ, Barco T, Zunt SL: Hydroxyapatite/PMMA composites as bone cements. Bio-medical materials and engineering. 14(1):87-105 (2004).

12. Koptyug A, Rännar L-E, Bäckström M, Fager Franzén MSS, Dérand DP: Additive Manufacturing Technology Applications Targeting Practical Surgery. International Journal of Life Science and Medical Research. 3(1):15-24 (2013).

13. Hench LL. Bioceramics: from concept to clinic. Journal of the American Ceramic Society. 74(7):1487-510 (1991).
14. Sousa S: Projeto conceitual de implante bioativo com gradiente de estrutura funcional em poli (metacrilto de metila) e hidroxiapatita. Análises: in vitro e in vivo. Universidade de Sao Paulo, Escola de engenharia de sao carlos- EESC; 2009.

15. Porous Surface Modified Bioactive Bone Cement for Enhanced Bone Bonding: http://journals.plos.org/plosone/article?id=10.1371/journal.pone.00425 25

16. Marbacher S, Andereggen L, Erhardt S, Fathi A-R, Fandino J, Raabe A, et al.: Intraoperative template-molded bone flap reconstruction for patient-specific cranioplasty. Neurosurgical Review. 35(4):527-35 (2012).

17. Stieglitz LH, Gerber N, Schmid T, Mordasini P, Fichtner J, Fung C, et al.: Intraoperative fabrication of patient-specific moulded implants for skull reconstruction: single-centre experience of 28 cases. Acta Neurochirurgica. 156(4):793-803 (2014)

18. Lewis G: Properties of acrylic bone cement- State of the art review. Department of Mechanical Engineering, The University of Memphis, Tennessee. (1997)

19. Rotaru H, Ba ciut, M, Stan H, Bran S, Chezan H, Iosif A, et al:. Silicone rubber mould cast polyethylmethacrylate-hydroxyapatite plate used for repairing a large skull defect. Journal of Cranio-Maxillofacial Surgery. 34(4):242-246 (2006).

20. Almasi D, Izman S, Sadeghi M, Iqbal N, Roozbahani F, Krishnamurithy G, et al.: In Vitro Evaluation of Bioactivity of Chemically Deposited Hydroxyapatite on Polyether Ether Ketone. International Journal of Biomaterials. 2015:1-5 (2015).

21. Calvo-Fernández T, Parra J, Vázquez B, López-Bravo A: Comportamiento biológico de cementos óseos acrílicos con compuestos antioxidantes derivados de la vitamina E. Biomecánica. 14(1): 16-29 (2008)

22. Carbonell GV, Alfieri AF, Alfieri AA, Vidotto MC, Levy CE, Darini ALC, et al.: Detection of cytotoxic activity on Vero cells in clinical isolates of Serratia marcescens. Brazilian journal of medical and biological research. 30(11):1291-1298 (1997)

23. Di Silvio L, Dalby MJ, Harper EJ, Bonfield W: In vitro evaluation of a new polymethylmethacrylate cement reinforced with hydroxyapatite. J Mater Sci Mater Med. 10(12):793-796 (1999).

24. Wang L YD, Spicer PP HA, Scott DW WM, Kasper FK MA. Characterization of porous polymethylmethacrylate space maintainers for craniofacial reconstruction. J Biomed Mater Res Part B 2013.101B:813-825 (2013)

25. Dahl OE, Garvik LJ, Lyberg T. Toxic effects of methylmethacrylate monomer on leukocytes and endothelial cells in vitro. Acta Orthopaedica. 65(2):147-153 (1994)

26. Jager M, Urselmann F, Witte F, Zanger K, Li X, Ayers DC, et al.: Osteoblast differentiation onto different biometals with an endoprosthetic surface topography in vitro. J Biomed Mater Res A 86(1):61-75. (2008)

27. Martin JY, Schwart Z, Hummert TW, Schraub DM, Simpson J, Lankford $\mathrm{J} \mathrm{Jr}$, et al.: Effect of titanium surface roughness on proliferation, differentiation and protein synthesis of human osteoblast-like cells (MG63). J Biomed Mater Res 29(3): 389-401. (1995)

28. Deligianni DD, Katsala N, Ladas S, Sotiropoulou D, Amedee J, Missirlis YF. Effect of surface roughness of the titanium alloy Ti-6Al-4V on human bone marrow cell response and on protein adsorption. Biomaterials 22(11): 1241-1251. (2001)

29. Drstvensek I, Hren NI, Strojnik T, Brajlih T, Valentan B, Pogacar V, et al. Applications of rapid prototyping in cranio-maxilofacial surgery procedures. Int J Biol Biomed Eng. 1:29-38. (2008)

$14^{\text {th }}$ LACCEI International Multi-Conference for Engineering, Education, and Technology: "Engineering Innovations for Global Sustainability", 20-22 July 2016, San José, Costa Rica. 


\title{
In vitro bioactive response of VERO-cells on polymethyl- methacrylate craniofacial implants altered with hydroxy- apatite/carboxymethylcellulose
}

\author{
Colcha Danny, Mechanical Engineer ${ }^{1}$, Cáceres Jefferson, Mechanical Engineer ${ }^{2}$, and Loayza Francis, $\mathrm{PhD}^{1}$ \\ ${ }^{1}$ Escuela Superior Politécnica del Litoral, Ecuador, dpcolcha@espol.edu.ec, floayza@espol.edu.ec \\ ${ }^{2}$ Escuela Superior Politécnica del Litoral, Ecuador, jefalcac@espol.edu.ec
}

\begin{abstract}
In Ecuador, intraoperative fabrication of polymethylmethacrylate (PMMA) craniofacial-implants is the norm when small sizes and simple geometry implants are required; this method has high infection risk, is inaccurate and unaesthetic. In this work we present a process for preoperative fabrication of craniofacial-implants using PMMA. For this study, a tomographic image of the head of a subject with a parietotemporal defect was used, the defect was then reconstructed using Blender ${ }^{\circledR}$ and Autodesk-Inventor ${ }^{\circledR}$ to generate a model of the implant. A 3D-printed model was used to fabricate a silicon-rubber mold; finally the implant was produced by casting. PMMA was also altered with $\mathrm{Hy}$ droxyapatite/Carboxymethyl-cellulose (Hap/CMC) in order to improve its bioactivity. VERO-cells were then used to test proliferation and adhesion on different combinations of PMMA/Hap/CMC. Results showed that probes altered with 5\%-Vol Hap and 10\%-Vol CMC had significantly better cell-growth when compared to unaltered-PMMA (Tukey HSD); in contrast, materials altered solely with carboxymethylcellulose showed cell-growth inhibitions/death. Overall, this manufacture approach showed highly aesthetic and functional outcomes when the final implant was compared against the 3D-printed skull defect, which renders this method as a viable option for the fabrication of PMMA implants meant to replace missing bone-flaps. Likewise, in vitro tests with Vero-cells suggest an improvement of implant-bioactivity with the addition of 5\%-Vol hydroxyapatite and 10\%-Vol CMC.
\end{abstract}

Keywords-Craniofacial, polymethylmethacrylate,

$3 D-$ printing, VERO, bioactivity.

\section{INTRODUCTION}

A craniofacial defect is a modification in the anatomy and morphology of the bone in this region, which could be congenital or acquired as a result of neurosurgical procedure. In Ecuador, 8.726 cases of intracranial traumatisms were registered just in 2014, corresponding to the $8^{\text {th }}$ cause of male morbidity with 6.232 incidents and 2.494 belonging to female. Out of these 8.726 cases, Pichincha and Guayas provinces had the greatest numbers of incidents in 2014, with 1.632 and 1.355 cases respectively [1]. Every year, 55\% of these incidents require surgical treatment in the craniofacial region [2].

Nowadays, procedures that repair these defects are complicated due to the complex anatomy involved and the requirement of highly aesthetic results. The main objectives of craniofacial reconstruction are: Restoring the protective barriers for intracranial structures in the skull, present pleasing aesthetic results, retrieve a permanent and durable reconstruction and in some cases bring back functionality of the damaged area [3]. The consequences of poor-quality interventions often

Digital Object Identifier (DOI): http://dx.doi.org/10.18687/LACCEI2016.1.1.080 ISBN: 978-0-9822896-9-3

ISSN: $2414-6390$ results in unaesthetic outcomes which may disturb the psychological state and social interaction of the patient [4].

A great variety of methods have been studied in order to repair craniofacial defects; autologous and/or allogenic bone grafts; and alloplastic bone substitutes are among the most common [5]. Although autologous grafts are always the first option, their extraction often comes with complications associated with the geometry of the extraction area which limits the shape and the final aesthetic result; and medical difficulties that may be presented at the donor site such as storage and age discrepancy of the donor, which are also a downside in allogenic bone grafts $[6,7]$.

On the other hand, numerous alloplastic materials have also been proven to be highly biocompatible such as: Polymethylmethacrylate (PMMA), Polyetheretherketone (PEEK), titanium alloys, stainless steel, chrome-cobalt alloys and ceramics such as Hydroxyapatite (HAp), to name a few [8]. While most of these materials are biocompatible, they are not naturally bioactive (except for titanium and HAp); this limits the implant materials surgeons can use in cases where the ability of implant-bone merging is necessary [9].

However, recent breakthroughs in biomedical technology have been reported in the development of osteoconductive alloplastic materials $[6,7,10,11]$. These osteoconductive counterparts differ in their ability to merge with the surrounding bone and improve anchorage of the implant at the boneimplant interface [12]. This osteoconductivity is mainly achieved by adding bioactive materials such as: Bioglass $₫$, bioglass-ceramics, calcium phosphate ceramics or hydroxyapatite [13]; or by increasing the porosity of the PMMA matrix with the aid of carboxymethylcellulose or alginate microparticles [14, 15], thus improving implant bioactivity by allowing bone ingrowth to the implant.

Regarding simple geometry/implantation craniofacial defects, PMMA implants are the most widely used due to their low-price, high malleability, radiopaque characteristics, resistance, light weight and of course biocompatibility [9]. In Ecuador; when the implantation and geometry of the defect is simple, the usual approach is to replace the damaged bone flap with intraoperative PMMA implants [16, 17]. Intraoperative PMMA implants can be harmful to the patient due to thermal\&chemical necrosis of the surrounding tissue when exothermic heat of polymerization occurs, as well as infection, decrease in blood pressure or allergic reactions caused by leaking of unpolymerized monomer $[11,18]$.

$14^{\text {th }}$ LACCEI International Multi-Conference for Engineering, Education, and Technology: "Engineering Innovations for Global Sustainability", 20-22 July 2016, San José, Costa Rica. 
The aim of this study is to develop a protocol for the design and manufacture of PMMA preoperative craniofacialimplants with the aid of 3D printing and silicon-rubber mold technics (SRM) [19]. The purpose of preoperative fabrication of PMMA implants is to avoid the disadvantages present in the intraoperative procedure; due to these processes happening outside the body and being given enough time to fully finish and stabilize. Additionally, the PMMA matrix will be altered with hydroxyapatite or carboxymethylcellulose as bioactive and porous agents, respectively [20]. Finally, bioactive tests will be conducted in order to compare proliferation/adhesion of VERO cells in different compositions and partially demonstrate the bioactive improvement of PMMA [21, 22].

\section{MATERIALS AND METHODS}

\section{Acquisition of tomographic images}

Axial tomographic images of the subject's head were collected in DICOM format, these belonged to a 33 year old male patient. The patient suffered from an intracranial traumatism and was submitted for a decompressive craniectomy short afterwards. The resulting parietotemporal defect in his left side was measured in the axial, coronal and sagittal axes with 82.59 $\mathrm{mm}, 80.45 \mathrm{~mm}$ and $83.77 \mathrm{~mm}$ respectively. The axial cuts were $1 \mathrm{~mm}$ of thickness and give a total of 301 slices recollected by the axial computerized tomograph (TOSHIBA aquilion).

\section{Image segmentation}

DICOM images were imported to 3DSLICER (Magn Reson Imagin. 2012 Nov). The segmentation was then conducted using the threshold technique with values between 230 and 270 in the Hounsfield scale. Finally the segmented image of the skull was exported in STL. (Stereo Lithography) format.

\section{Reconstruction of the craniofacial defect}

The tridimensional-image in STL. format was reconstructed using BLENDER (Amsterdam: Blender Foundation, 1998). The basic idea was to mirror the entire skull by a midsagittal plane and then perform the Boolean operation of subtracting this mirrored-skull from the original in order to obtain a 3D-model of the missing bone flap. However, due to the position of the CT-scanning a mid-sagittal plane of symmetry was approximated by using well-defined features of the skull (nose and eye cavities). The 3D-model of the implant was manually fixed utilizing Blender software's tools and then exported in STL. to be 3D-printed (PROJECT 3510 SD, 3DS). The defect of the skull was also 3D-printed in ceramic (ZPRINTER 310 Plus, ZCorporation) in order to later test the accuracy, proper fit of the implant and the final aesthetic result.

\section{Manufacture of the probes}

Zimmer Bone-Cement (Dough Type) was used to fabricate probes $15 \mathrm{~mm}$ in diameter and $2 \mathrm{~mm}$ in thickness. Zimmer Bone-Cement package contains: 40 grams of Polymethylmethacrylate containing barium sulfate and $20 \mathrm{ml}$ of a liquid component containing mainly methylmethacrylate $(97.25 \%)$.
The manufacturer suggests the use of a 1:1 ratio (polymer powder/liquid monomer) for Dough type bone cement, but since a low viscosity bone cement was needed in order to be able to inject it into a mold cavity; a $0.75: 1$ ratio was used. Also, in order to stretch handling time, prechilling of the liquid monomer in $-4{ }^{\circ} \mathrm{C}$ was necessary. Additionally, a geometric model of a cubic cell containing spheres was used to approximately correct the volume represented by the powder in order to fill the empty spaces (air) between the PMMA/Hap spheres and wet all the components completely.

Carboxymethylcellulose was used to manufacture porous probes; this material was mixed with water $(40 \mathrm{mg} / \mathrm{ml})$ in order to form a gel. The gel was then mixed with the powder components of the bone cement and then the process continued according to the manufacturer's manual. On the other hand probes containing Hydroxyapatite were manufacture by first mixing all the powder components (PMMA and Hap) in the respective volume percentages and then adding the liquid monomer. In both cases, the volume percentage of liquid monomer was calculated in a manner so that it will only react with the powder components in the mixture, i.e. Hap and PMMA. In order to sterilize probes, they were washed 3 times with hot water (approximately $88{ }^{\circ} \mathrm{C}$ ), then rinsed one last time with cold water, disinfected with $99 \%$ ethanol and placed in UV camera for 15 minutes.

Table I and Table II show 5 different compositions studied, where every probe was replicated 12 times accounting for 3 days of experimentation.

\section{Improvement of surface bioactivity}

In order to prove bioactivity enhancement of the PMMA, VERO-cells (African green monkey kidney cells) were cultivated for 24 hours in a $\mathrm{CO}_{2}$ Incubator at $37{ }^{\circ} \mathrm{C}$ and $5 \% \mathrm{CO}_{2}$ with Dulbecco's Modified Eagle Medium (DMEM, Gibco), supplemented with $10 \%$ fetal bovine serum and $1 \mathrm{X}$ Antibiotic-Antimycotic at an initial population of $6 \times 10^{4}$ cells.

After incubation, cells were distributed among 3 different 24well cell-culture plates containing the different probes and a Control so that they could be studied in intervals of 24,48 and 72 hours. Cells cultivated directly on polystyrene at $37{ }^{\circ} \mathrm{C}$ and $5 \% \mathrm{CO}_{2}$ in a solution with DMEM, $10 \%$ fetal bovine serum, $1 \mathrm{X}$ Antibiotic-Antimycotic were used as a Control, representing the best case-scenario for cell-growth and simultaneously acting as the maximum cell-growth limit. Every day, cells from each composition were cleaved with Trypsin-EDTA $0.25 \%$ and then dyed with Trypan Blue stain $0.4 \%$ in order to perform 4 random cell counts (per composition, including the control) with a hemocytometer. An N-WAY ANOVA $(\mathrm{p}<$ $0.05)$ was performed to determine cell-growth differences between substrates. Later on, a ONE-WAY ANOVA $(\mathrm{p}<0.05)$ analyzed daily differences among substrates and Tukey HSD was used to compare them against probe D (unaltered bone cement) and each other in order to determine if the differences were significant. 
Table I

Composition of substrates A-C with Carboxymethylcellulose and hydroxyapatite as porogenic and bioactive agents

\begin{tabular}{|c|c|c|c|c|c|c|c|c|c|}
\hline \multirow[t]{2}{*}{ Material } & \multicolumn{3}{|c|}{ Substrate A } & \multicolumn{3}{|c|}{ Substrate B } & \multicolumn{3}{|c|}{ Substrate C } \\
\hline & $\%$ Volume. & grams & $\mathrm{mL}$ & $\%$ Volume. & grams & $\mathrm{mL}$ & $\%$ Volume. & grams & $\mathrm{mL}$ \\
\hline $\begin{array}{c}\text { Porosity [CMC + } \\
\left.\mathrm{H}_{2} \mathrm{O}\right]\end{array}$ & $40,0 \%$ & & & $20,0 \%$ & & & $10,0 \%$ & & \\
\hline PMMA & $60,0 \%$ & 1,482 & $\begin{array}{c}2,40 \\
0\end{array}$ & $80,0 \%$ & 1,977 & $\begin{array}{c}3,20 \\
0\end{array}$ & $85,0 \%$ & 2,100 & $\begin{array}{c}3,40 \\
0\end{array}$ \\
\hline MMA $(1: 0,75)$ & - & 0,929 & $\begin{array}{c}0,98 \\
9 \\
\end{array}$ & - & 1,239 & $\begin{array}{c}1,31 \\
8 \\
\end{array}$ & - & 1,316 & $\begin{array}{c}1,40 \\
0\end{array}$ \\
\hline $\mathrm{CMC}$ & $1,6 \%$ & 0,101 & $\begin{array}{c}0,06 \\
4\end{array}$ & $0,8 \%$ & 0,050 & $\begin{array}{c}0,03 \\
2\end{array}$ & $0,4 \%$ & 0,025 & $\begin{array}{c}0,01 \\
6 \\
\end{array}$ \\
\hline Water & $38,4 \%$ & 1,536 & $\begin{array}{c}1,53 \\
6\end{array}$ & $19,2 \%$ & 0,768 & $\begin{array}{c}0,76 \\
8\end{array}$ & $9,6 \%$ & 0,384 & $\begin{array}{c}0,38 \\
4\end{array}$ \\
\hline Hap & - & & & - & & & $5,0 \%$ & 0,331 & $\begin{array}{c}0,20 \\
0\end{array}$ \\
\hline Total volume & & & $\begin{array}{c}4,00 \\
0\end{array}$ & & & $\begin{array}{c}4,00 \\
0\end{array}$ & & & $\begin{array}{c}4,00 \\
0\end{array}$ \\
\hline
\end{tabular}

Table II

Nonporous composition of Substrate D and Substrate E (hydroxyapatite as bioactive agent)

\begin{tabular}{ccccccc}
\hline \multirow{2}{*}{ Material } & \multicolumn{3}{c}{ Substrate D } & \multicolumn{3}{c}{ Substrate E } \\
\cline { 2 - 7 } & Volume. & Grams & $\mathrm{mL}$ & Volume. & Grams & $\mathrm{mL}$ \\
\hline PMMA & $100 \%$ & 2,471 & 4,000 & $70 \%$ & 1,730 & 2,800 \\
\hline MMA $(1: 0,75)$ & - & 1,548 & 1,648 & - & 1,084 & 1,153 \\
\hline Hap & - & - & - & $30 \%$ & 1,983 & 1,200 \\
\hline Total Volume & - & & 4,000 & - & & 4,000 \\
\hline
\end{tabular}

\section{Optical Microscopy}

Images of each well (A,B,C,D,E,Control) were taken in the MOTIC AE30-21 inverted microscope every 24 hours with the MOTICAM PRO 282B in order to observe changes in cell-growth and register cell development at 10X magnification. Finally, 2 wells per composition (except Control) were fixed with paraformaldehyde 4\% diluted in Phosphate Buffered Saline (PBS) and incubated at room temperature for an hour; eventually the medium (containing paraformaldehyde) was removed and fresh PBS was added in order to take images of the probe's surface with the aid of the ZEISS upright microscope (20X magnification) and an external CANON Powershot 14.7 pixels camera. Cell growth on top of the different materials was expected and qualitative characterization of the material's bioactivity was performed.

\section{Manufacture of the implant}

A silicon rubber mold was fabricated using the 3D printed model of the implant. Sprues for injection and escape of the material were added on opposite limits of the implant's mold. The mold was left to dry for 3 hours until it set, then cut open to remove the implant model and resealed in order to be used. Polymethylmethacrylate-based Zimmer Bone Cement in $0.75: 1$ ratio was injected into the mold until the material came out from the escape sprue. Finally the implant's accuracy was qualitatively tested against the 3D-printed defect of the skull.

\section{RESULTS}

\section{Improvement of surface bioactivity}

Cells cultivated in the control group proved to have the largest cell count in each day, leading the group as a maximum cell growth limit as expected. The analysis of N-WAY ANOVA showed that there are no major differences between daily replicas per composition ( $\mathrm{F}=0.49, \mathrm{p}>0.05)$. Results of the $\mathrm{N}$-Way Anova also exhibited dependence of replications on sample compositions $(\mathrm{F}=2.13, \mathrm{p}<0.05)$, and dependence of daily samples on replications $(\mathrm{F}=2.4, \mathrm{p}<0.05)$, both which are logical and will not be analyzed. The interaction to be analyzed is SUBSTRATE*DAY as shown on Fig.1, which represents the dependence of daily cell count on the different substrates $(\mathrm{F}=59.41, \mathrm{p}<0.05)$.

Day 1. - In the first 24 hours cells in substrate A, B and C developed in a way that did not show significant differences against probe D (Tukey HSD). In the first day, only substrate E showed to have improved cell growth compared to D. In all

14 ${ }^{\text {th }}$ LACCEI International Multi-Conference for Engineering, Education, and Technology: "Engineering Innovations for 
cases cell counts were below the upper limit constrained by the Control substrate (Tukey HSD).

Day 2. - After 48 hours, only probe A had no significant difference against probe D (Tukey HSD). The rest of the probes showed significant differences, regarding positive and negative behaviors. Positive results represent enhancement on proliferation of cells in substrates $\mathrm{C}$ and $\mathrm{E}$, with $\mathrm{C}$ having substantially higher cell count than $\mathrm{E}$, but still below the upper limit imposed by the Control substrate (Tukey HSD). Negative results in substrate $\mathrm{B}$, showed a significant decrease in cell count compared to D (Tukey HSD).

Day 3. - After 72 hours of experimentation the same results were observed. Substrate B showed bioactive decrease compared to $\mathrm{D}$ and substrate A proved being not significantly different than D (Tukey HSD). Again substrate C and E showed improvements on cell proliferation; with $\mathrm{C}$ being better than $\mathrm{D}$, not significantly different than $\mathrm{E}$ but still below the Control substrate (Tukey HSD).
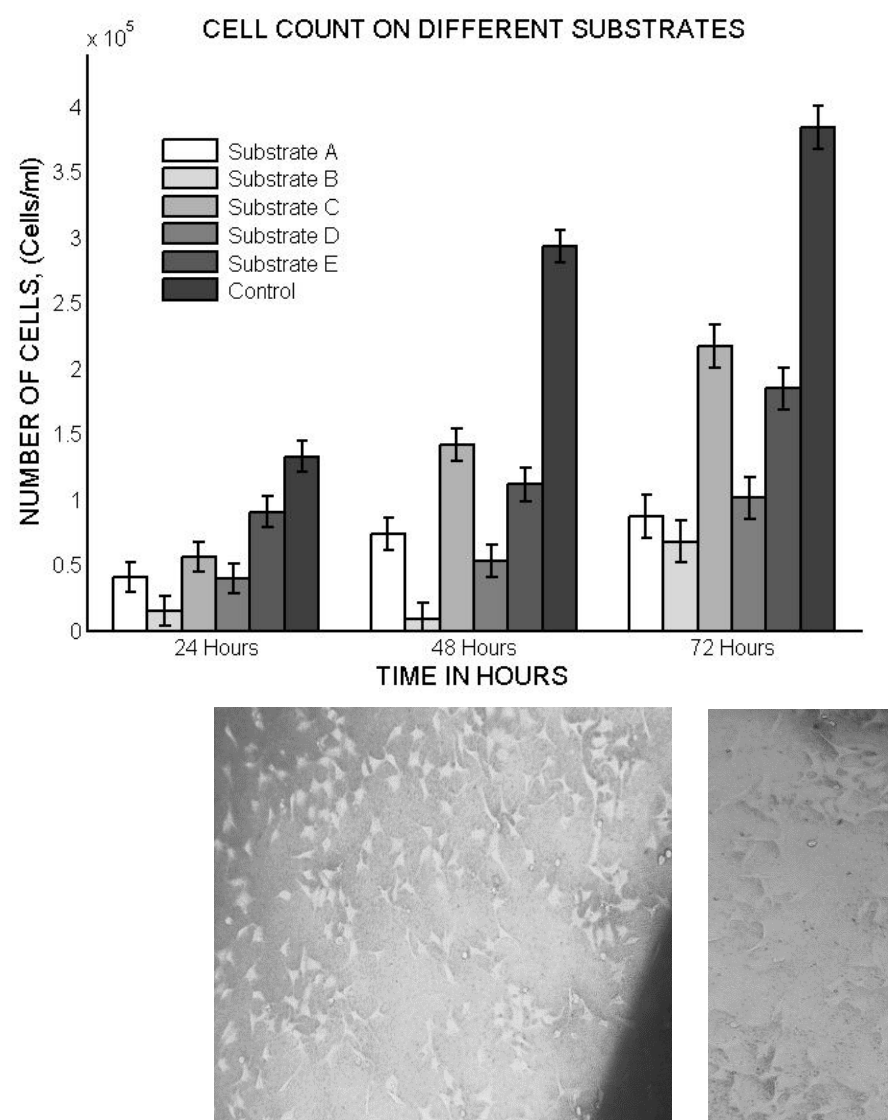

A
Fig. 1. Daily cell-growth variations of VERO cells on different substrates $(\mathrm{p}<0.05)$. Multi-comparison analysis performed by Tukey HSD

\section{Optical Microscopy, qualitative assessment}

-Cell culture, Day 1

Fig 2. shows the development of cell culture on the medium around the different probes. Substrate A and B showed signs of a dirty mediums with good development of VERO cells. On the other hand substrate $\mathrm{C}$ and $\mathrm{E}$ showed very good clean mediums as in substrate D and the Control. Cells on C, D and E look well grown, elongated and with very few signs of dead cells.

Fig. 3. shows the surface of the different substrates to partially demonstrate the bioactivity of the material. In Probe A and B, there's no sign of cell attachment on the surface. In contrast, substrate C, D and E show clear growth of healthy cells on their surfaces; with Probe D and E being the ones with visually higher proliferation of cells. Substrate E showed a much clear difference between cells boundaries, as they are more spaced and clearly defined compared to substrate D.

\section{-Cell culture, Day 2}

Fig. 4. Shows no major differences between Probe A and B from previous days as their medium looks dirty and cloudy; still cells appear to have developed correctly and are well grown and elongated. On the other hand, cells on probe $\mathrm{C}$ and E look very much as the Control, which shows they are healthy; unlike cells on probe $\mathrm{D}$, which look deteriorated as they are more spaced and less confluent as they were on day 1.

Fig. 2. Cell growth on medium around different substrates (After 24 hours) 


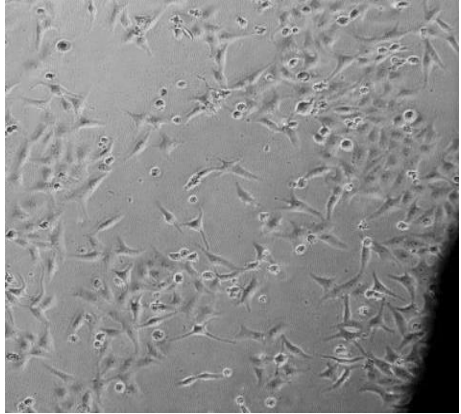

$\mathrm{D}$

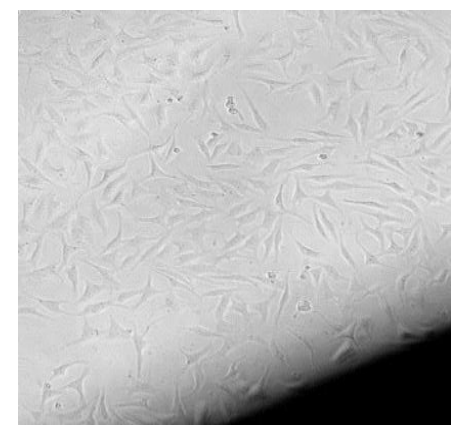

$\mathrm{E}$

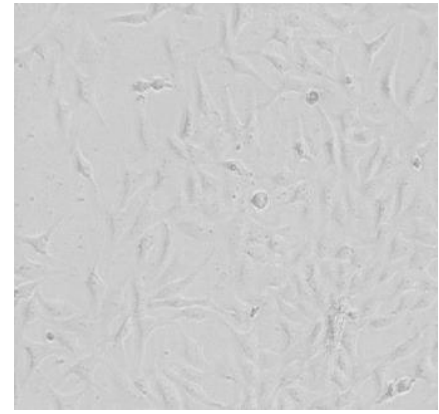

Control

Fig. 2. Cell growth on medium around different substrates (After 24 hours)

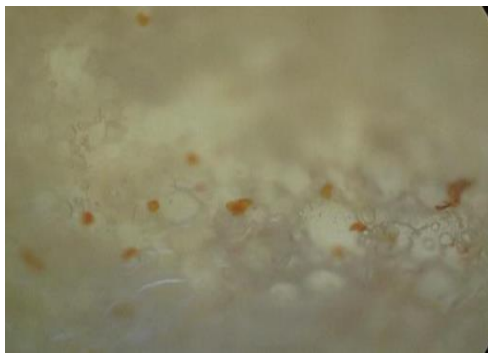

$\mathrm{A}_{1}$

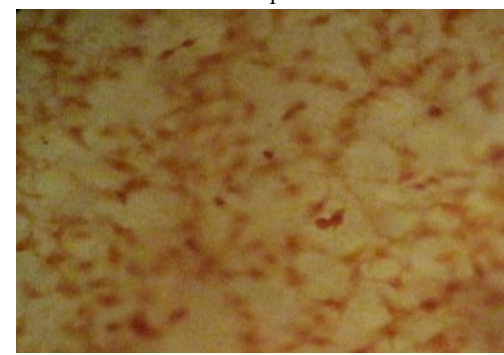

$\mathrm{D}_{1}$

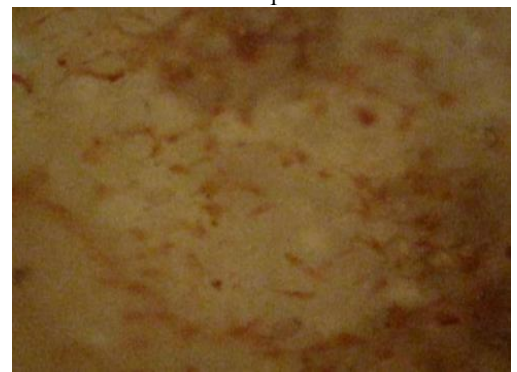

$\mathrm{B}_{2}$

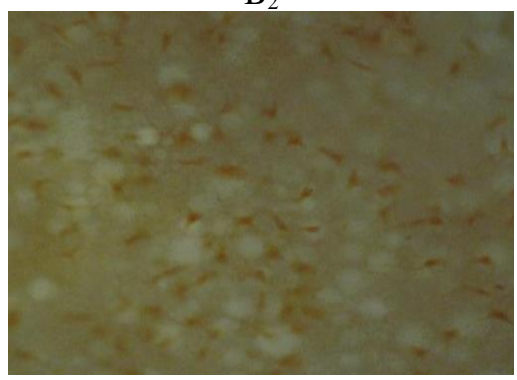

$\mathrm{E}_{2}$

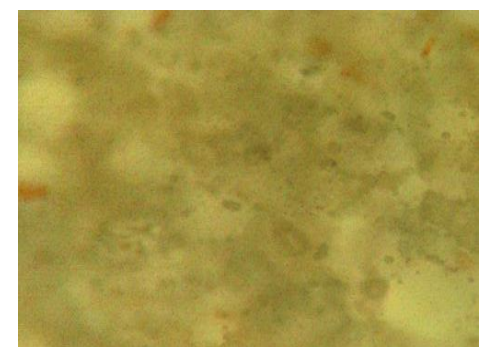

$\mathrm{B}_{1}$

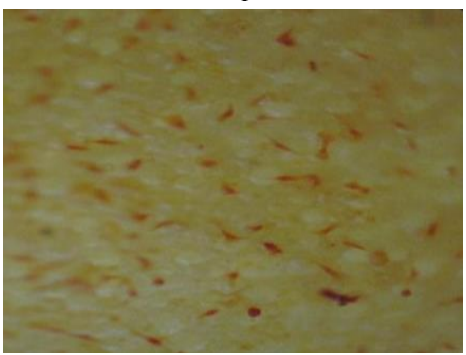

$\mathrm{E}_{1}$

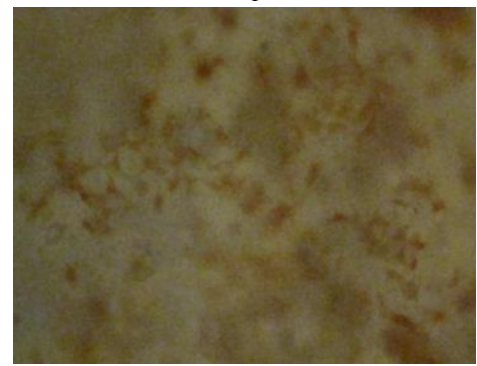

$\mathrm{C}_{2}$

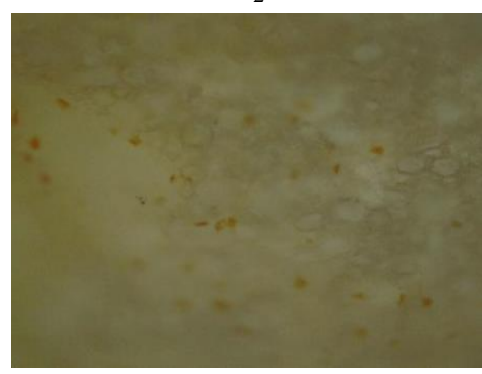

$\mathrm{A}_{3}$

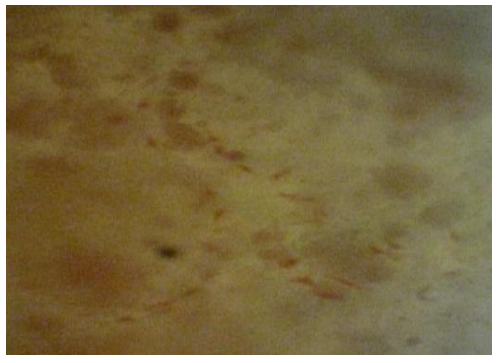

$\mathrm{C}_{1}$

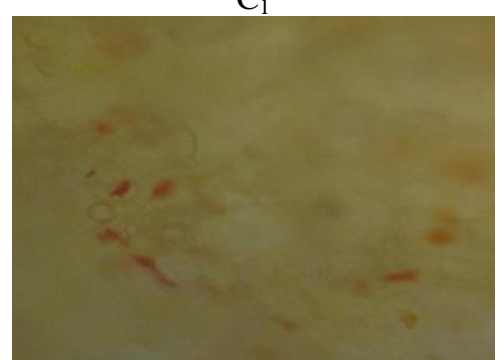

$\mathrm{A}_{2}$

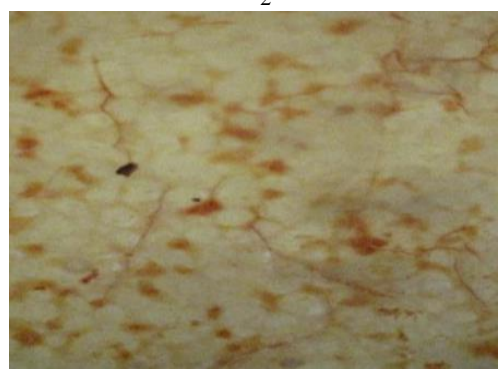

$\mathrm{D}_{2}$

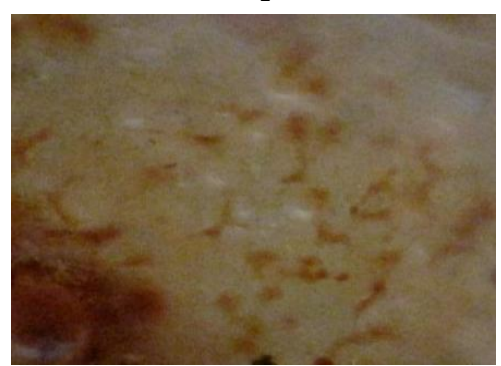

$\mathrm{B}_{3}$

$14^{\text {th }}$ LACCEI International Multi-Conference for Engineering, Education, and Technology: "Engineering Innovations for Global Sustainability", 20-22 July 2016, San José, Costa Rica. 


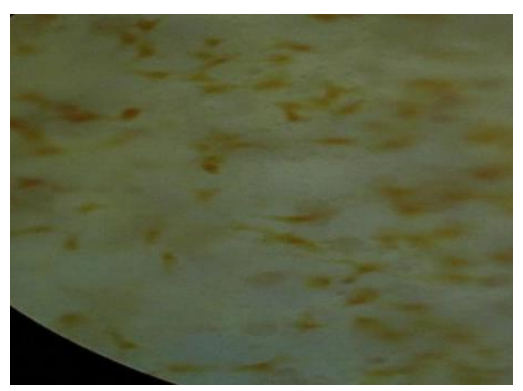

$\mathrm{C}_{3}$

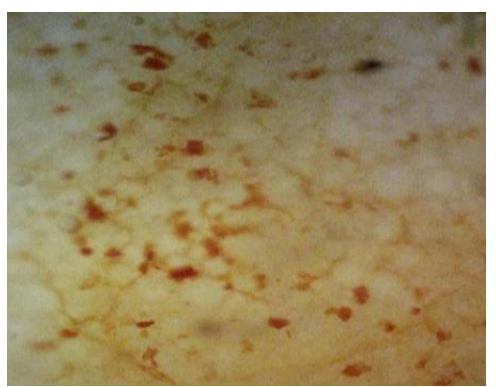

$\mathrm{D}_{3}$

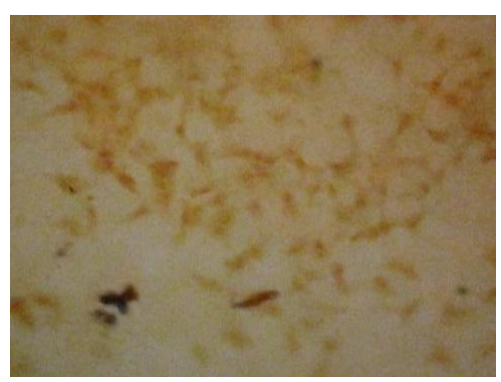

$\mathrm{E}_{3}$

Fig. 3. Cell proliferation and adhesion on the surface of different substrates. Subscripts stand for the day when the images were taken $\left(24\right.$ hours 1 ; $48 \mathrm{hours}_{2}$; 72 hours $_{3}$ )

A look at the material's surface Fig. 3, shows us the same results from previous days. Probe A has organic material that is dead, no sign of alive cells anywhere on its surface. In contrast, Probe B seemed to have developed a bioactive surface, since there are healthy cells attached to its surface. Probe C and $\mathrm{E}$ have a greater confluency of healthy cells compared to day 1 . On the contrary, cells on probe $\mathrm{D}$ seem to have lost its shape, they also look deteriorated as they no longer are elongated and well grown.

\section{-Cell culture, Day 3}

Last day of testing Fig. 5, cells from surrounding substrate A and B reached confluency but the medium is dirty and cloudy due to small unidentifiable particles. Again cells on Probe C, $\mathrm{D}$ and $\mathrm{E}$ look very healthy and the medium in all of them is clear, but full-confluency has only been reached on probe $\mathrm{C}$, as probe $\mathrm{D}$ and $\mathrm{E}$ are spaced and not filling the spaces completely.

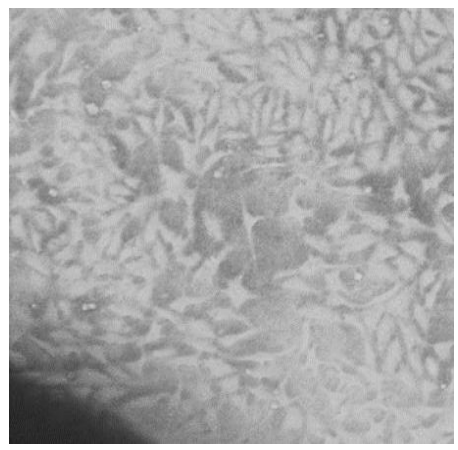

A

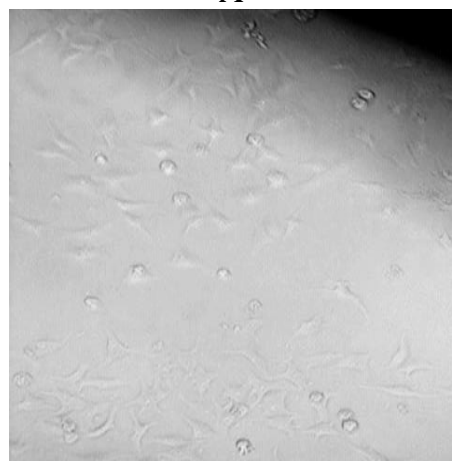

D

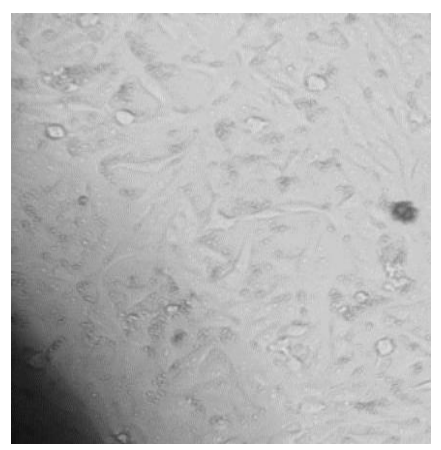

B

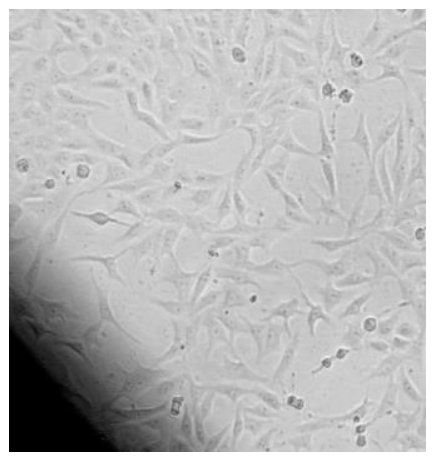

$\mathrm{E}$

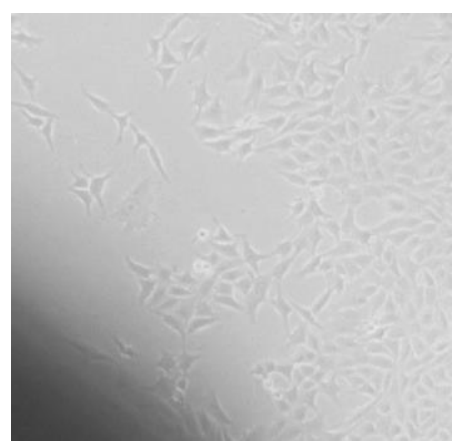

C

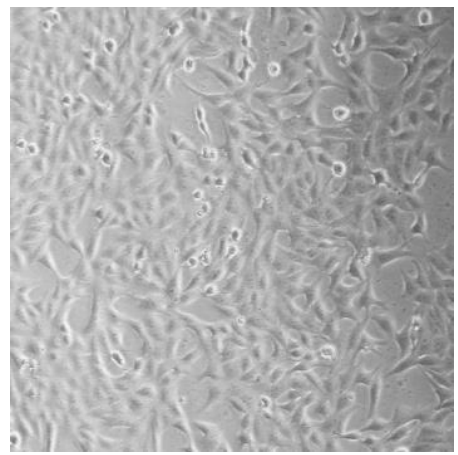

Control

Fig. 4. Cell growth on medium around different substrates (After 48 hours)

$14^{\text {th }}$ LACCEI International Multi-Conference for Engineering, Education, and Technology: "Engineering Innovations for Global Sustainability”, 20-22 July 2016, San José, Costa Rica. 


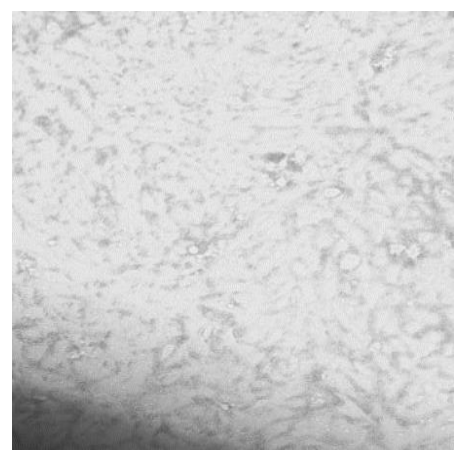

A

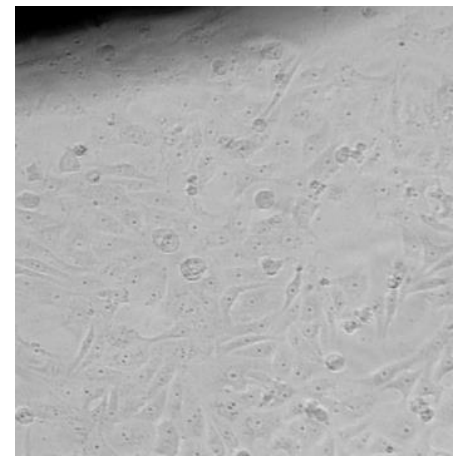

$\mathrm{D}$

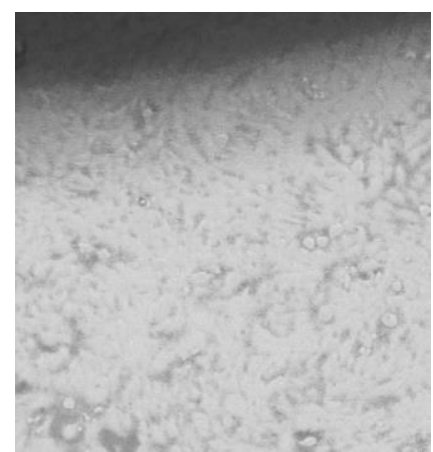

B

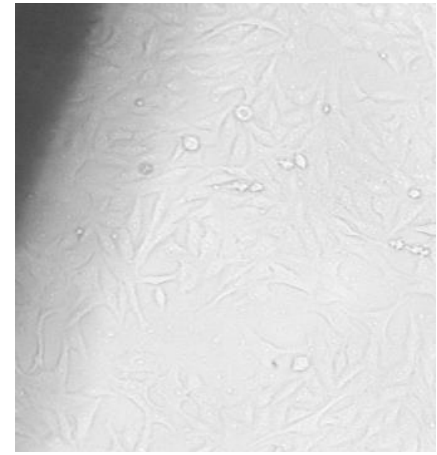

$\mathrm{E}$

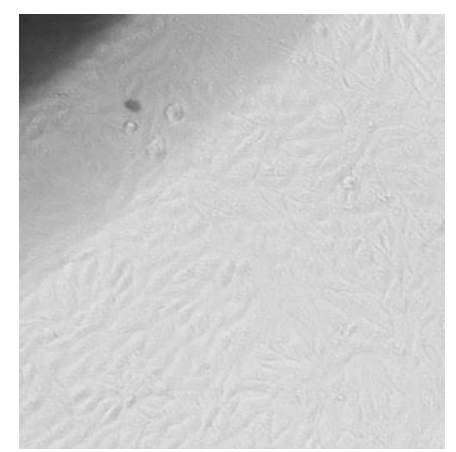

C

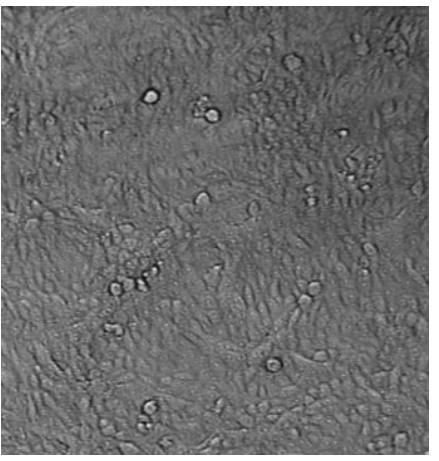

Control

Fig. 5. Cell growth on medium around different substrates (After 72 hours)

\section{Manufacture of the implant}

In order to prove this process viability, SRM in conjunction with 3D-printing techniques were used to manufacture a simple bone cement implant (substrate D). Qualitative assessment of the implant's fitting and accuracy indicated very good adaptation of the implant to the defect and the contour of the skull, thus producing a highly pleasing aesthetic and functional result Fig. 6.

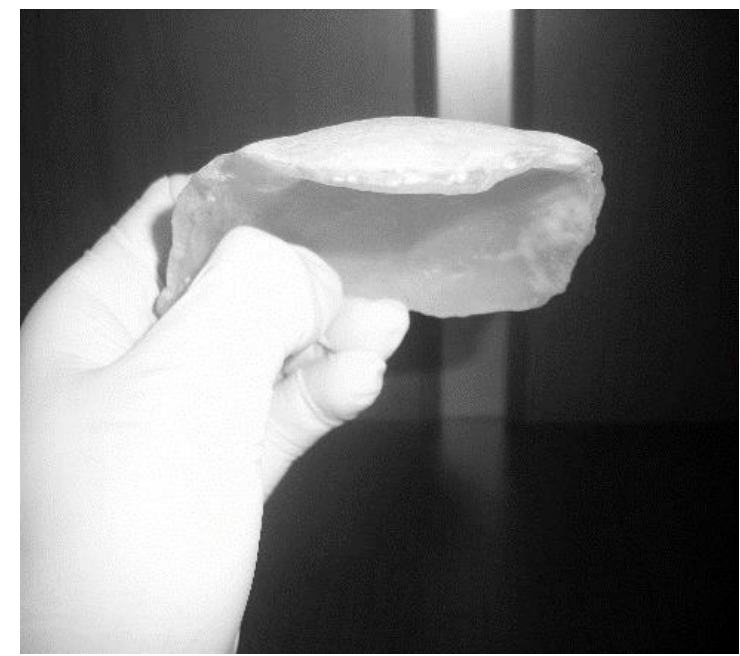

Fig. 6. a) Bone cement implant.

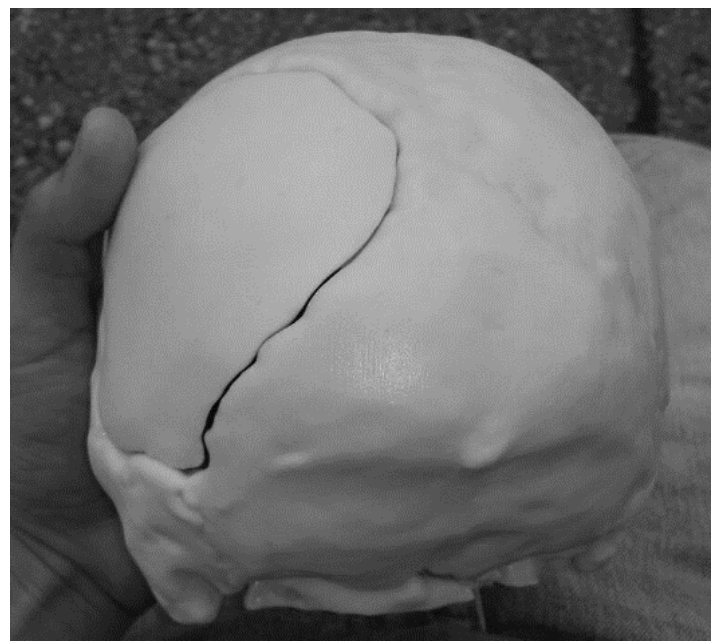

Fig. 6. b) Fitting of implant on the parietotemporal defect

\section{DISCUSSION}

\section{Improvement of surface bioactivity}

Results suggest that by the first day, surface bioactivity was significantly enhanced by the adding of hydroxyapatite alone, as showed by the results provided in substrate E which exhibited a higher cell count, improvement on cell adhesion and proliferation on the substrate when compared to substrate D. 
Probes containing Hydroxyapatite exhibited an overall bioactive behavior, thus increasing proliferation and adhesion of VERO cells to the substrate [23], even on probes containing as little as 5\% Hap (Substrate C). On the contrary, the decrease of living cells in probe A and B may be due to porous PMMA formulations often releasing unconverted methylmethacrylate (MMA) monomer [24]; this monomer is toxic for cells [25], which translates to death, enlargement and alteration of the shape of the cells as it was visually observed in microscopy. Fragmentation of the cells in probes A and B was also observed; these fragments were observed drifting in the medium and gave it the dirty and cloudy look we observed in the microscopy. As a result we consider that CMC gel as a porous agent in the percentages presented in probes $\mathrm{A}$ and $\mathrm{B}$, cannot be considered as enhancers of bioactivity due to the lack of adhesion of cells to the respective substrates; since in the case of probe B, the porosity causes death and lack of adhesion of cells in the substrate; and in the case of probe A, no major differences in cell count were spotted and there was almost no adhesion or proliferation of VERO cells in the substrate, thus not presenting real improvement on bioactivity.

Together with probe $\mathrm{A}$ and $\mathrm{B}$, probe $\mathrm{C}$ also had a slow proliferation of cells due that it contained $10 \%$ porosity which would have also released toxic monomer. The fact that it recovered by the second and third day and reached probe E's cell count ( $0 \%$ porosity), may suggest the amount of porosity did not affect the overall development of cell growth (as it did with substrates A and B), as the content of unconverted MMA may have been negligible. On probe D we observed proliferation and a decreasing cell attachment on the substrate which could be attributed to the inherent surface roughness of the unaltered bone cement (since no bioactive components were introduced in the matrix); as surface roughness in biomaterials has been proven to induce adhesion and proliferation of cells in the substrate [26, 27]. Even though surface roughness may have played an important role on cell adhesion, in this case in particular it may have not been sufficient to maintain adhesion and support further proliferation, as deterioration of the shape of the cells was observed in optical microscopy. To further assess the degree in which cement surface roughness influenced bioactivity in the substrate, a surface roughness test must be conducted [28].

\section{Manufacture of the implant}

Regarding the quality and accuracy of fit of the implant, we can conclude that 3D-printing in conjunction with Siliconrubber mold (SRM) techniques can produce high quality bone cement implants [29]; as the final result was tested visually on the cranial defect to demonstrate its accuracy and pleasing aesthetic result. All of this was possible due to the correct choosing of segmentation values for skull bones and the appropriate posterior reconstruction in Blender; which suggest that free software like 3D-Slicer and Blender could be used as a cheaper alternative for craniofacial reconstruction of simple geometry defects (mainly calvarial bone defects) as it offers the same level of accuracy of other paid-software packages. The present study demonstrated that generic bone cement compositions can be altered in order to produce compositions with positive effects on VERO cell cultures; also 3D-printing along with SRM techniques were presented as a cheap alternative in the manufacture of bioactive PMMA implants if paired up with free-software as 3D-Slicer and Blender. In the future if implantation were to happen, studies including Bone marrow derived Mesenchymal Stem Cells need to be performed in a similar way VERO cells were applied to this study; with the addition of in vivo studies and a deeper examination on morphology of the porosity, assessment of cell adhesion at higher magnifications (SEM Imaging), surface roughness and chemical composition of the altered material.

\section{AKNOWLEDGEMENTS}

This work has been partially financed by 'Aplicación de prototipado rápido para la construcción de modelos e implantes ortopédicos' Investigation Project and is part of the Thesis 'Aplicación de técnicas de manufactura aditiva para la fabricación de implantes cráneo-maxilofaciales de polimetilmetacrilato'. The authors wish to express their gratitude to the 'Laboratorio de Biomedicina' ESPOL's team for their interest in this dissertation.

\section{REFERENCES}

1. Anuario camas Egresos Hospitalarios 2014. Dirección de estadísticas sociodemográficas: Instituto Nacional de Estadísticas y Censos, http://www.ecuadorencifras.gob.ec

2. Oñate C., Oñate D., Granda A., Arias C: Análisis Epidemiológico de Trauma Maxilofacial. Revista médica de nuestros hospitales. 18:14-19 (2012)

3. Artico M, Ferrante L, Pastore FS, Ramundo EO, Cantarelli D, Scopelliti D, et al: Bone autografting of the calvaria and craniofacial skeleton. Surgical Neurology. 60(1):71-79 (2003)

4. Márquez M. F. L. Aspectos Psicológicos de pacientes que presentan hendidura Labio Palatina. Acta Odontológica Venezolana. 51( $\left.\mathrm{N}^{\circ} 2\right)$, (2013)

5. Bone Graft. Healthline: http://www.healthline.com/health/bone-graft

6. Cabraja M, Klein M, Lehmann T-N: Long-term results following titanium cranioplasty of large skull defects. Neurosurgical focus. 26(6):E10 (2009)

7. Breitbart AS, Ablaza VJ: Implant materials. Grabb and Smith's Plastic Surgery, 5th Ed Philadelphia: Lippincott-Raven. (1997)

8. Aydin S, Kucukyuruk B, Abuzayed B, Aydin S, Sanus GZ. Cranioplasty: Review of materials and techniques. J Neurosci Rural Pract. 2(2):162-167 (2011)

9. Navarro M, Michiardi A, Castano O, Planell J: Biomaterials in orthopaedics. Journal of The Royal Society Interface. 5(27):1137-1158 (2008).

10. Neumann A, Kevenhoerster K: Biomaterials for craniofacial reconstruction. GMS current topics in otorhinolaryngology, head and neck surgery. Vol 9 (2009)

11. Chu KT, Oshida Y, Hancock EB, Kowolik MJ, Barco T, Zunt SL: Hydroxyapatite/PMMA composites as bone cements. Bio-medical materials and engineering. 14(1):87-105 (2004).

12. Koptyug A, Rännar L-E, Bäckström M, Fager Franzén MSS, Dérand DP: Additive Manufacturing Technology Applications Targeting Practical Surgery. International Journal of Life Science and Medical Research. 3(1):15-24 (2013). 
13. Hench LL. Bioceramics: from concept to clinic. Journal of the American Ceramic Society. 74(7):1487-510 (1991).

14. Sousa S: Projeto conceitual de implante bioativo com gradiente de estrutura funcional em poli (metacrilto de metila) e hidroxiapatita. Análises: in vitro e in vivo. Universidade de Sao Paulo, Escola de engenharia de sao carlos- EESC; 2009.

15. Porous Surface Modified Bioactive Bone Cement for Enhanced Bone Bonding:

http://journals.plos.org/plosone/article?id=10.1371/journal.pone. 00425 25

16. Marbacher S, Andereggen L, Erhardt S, Fathi A-R, Fandino J, Raabe A, et al.: Intraoperative template-molded bone flap reconstruction for patient-specific cranioplasty. Neurosurgical Review. 35(4):527-35 (2012).

17. Stieglitz LH, Gerber N, Schmid T, Mordasini P, Fichtner J, Fung C, et al.: Intraoperative fabrication of patient-specific moulded implants for skull reconstruction: single-centre experience of 28 cases. Acta Neurochirurgica. 156(4):793-803 (2014)

18. Lewis G: Properties of acrylic bone cement- State of the art review. Department of Mechanical Engineering, The University of Memphis, Tennessee. (1997)

19. Rotaru H, Ba ciut, M, Stan H, Bran S, Chezan H, Iosif A, et al:. Silicone rubber mould cast polyethylmethacrylate-hydroxyapatite plate used for repairing a large skull defect. Journal of Cranio-Maxillofacial Surgery. 34(4):242-246 (2006).

20. Almasi D, Izman S, Sadeghi M, Iqbal N, Roozbahani F, Krishnamurithy $\mathrm{G}$, et al.: In Vitro Evaluation of Bioactivity of Chemically Deposited Hydroxyapatite on Polyether Ether Ketone. International Journal of Biomaterials. 2015:1-5 (2015).

21. Calvo-Fernández T, Parra J, Vázquez B, López-Bravo A: Comportamiento biológico de cementos óseos acrílicos con compuestos antioxidantes derivados de la vitamina E. Biomecánica. 14(1): 16-29 (2008)

22. Carbonell GV, Alfieri AF, Alfieri AA, Vidotto MC, Levy CE, Darini ALC, et al.: Detection of cytotoxic activity on Vero cells in clinical isolates of Serratia marcescens. Brazilian journal of medical and biological research. 30(11):1291-1298 (1997)

23. Di Silvio L, Dalby MJ, Harper EJ, Bonfield W: In vitro evaluation of a new polymethylmethacrylate cement reinforced with hydroxyapatite. $\mathrm{J}$ Mater Sci Mater Med. 10(12):793-796 (1999).

24. Wang L YD, Spicer PP HA, Scott DW WM, Kasper FK MA. Characterization of porous polymethylmethacrylate space maintainers for craniofacial reconstruction. J Biomed Mater Res Part B 2013.101B:813-825 (2013)

25. Dahl OE, Garvik LJ, Lyberg T. Toxic effects of methylmethacrylate monomer on leukocytes and endothelial cells in vitro. Acta Orthopaedica. 65(2):147-153 (1994)

26. Jager M, Urselmann F, Witte F, Zanger K, Li X, Ayers DC, et al.: Osteoblast differentiation onto different biometals with an endoprosthetic surface topography in vitro. J Biomed Mater Res A 86(1):61-75. (2008)

27. Martin JY, Schwart Z, Hummert TW, Schraub DM, Simpson J, Lankford $\mathrm{J} \mathrm{Jr}$, et al.: Effect of titanium surface roughness on proliferation, differentiation and protein synthesis of human osteoblast-like cells (MG63). J Biomed Mater Res 29(3): 389-401. (1995)

28. Deligianni DD, Katsala N, Ladas S, Sotiropoulou D, Amedee J, Missirlis YF. Effect of surface roughness of the titanium alloy Ti-6Al-4V on human bone marrow cell response and on protein adsorption. Biomaterials 22(11): 1241-1251. (2001)

29. Drstvensek I, Hren NI, Strojnik T, Brajlih T, Valentan B, Pogacar V, et al. Applications of rapid prototyping in cranio-maxilofacial surgery procedures. Int J Biol Biomed Eng. 1:29-38. (2008)

$14^{\text {th }}$ LACCEI International Multi-Conference for Engineering, Education, and Technology: "Engineering Innovations for Global Sustainability", 20-22 July 2016, San José, Costa Rica. 
$14^{\text {th }}$ LACCEI International Multi-Conference for Engineering, Education, and Technology: "Engineering Innovations for Global Sustainability", 20-22 July 2016, San José, Costa Rica. 